\title{
TÜRK VE KAZAK HUKUKUNDA YABANCI YATIRIMLARIN TEŞVIKI**
}

\author{
DOI: $10.33717 /$ deuhfd.567634
}

\section{Dr. $\ddot{O} \breve{g r}$. Üyesi Salimya GANIYEVA ${ }^{* *}$}

\section{$\ddot{O} \mathbf{z}$}

Gelişmekte olan ülkelerin iç kaynaklarının yetersizliği, dış kaynaklı yatırım araçlarının ülkeye çekilmesi ihtiyacını doğurmaktadır.

Birçok gelişmekte olan ülke, kalkınma sürecinde ihtiyaç duyduğu dış kaynak ve teknolojiyi sağlamak için yabancı yatırımcılara vergi ve teşvik paketleri önermektedir. Ancak sadece bu yöntemlerin uygulanmasl yabancı yatırımların çekilmesi bakımından yetersiz kalmaktadır. Zira yabancı yatırımcı, kendi ülkesinin dışında bir başka ülkede yatırım yapmaya karar verirken, yatırım yapacă̆ ülkenin ekonomik ve politik istikrarını, yeterli potansiyel talebinin mevcudiyetini, hammaddeye ulaşma ve üretimin etkin bir şekilde yapılma imkânı gibi faktörleri de göz önünde bulundurmaktadır.

Ayrıca, güvenli yatırım ortamının sağlanması açısından ılımlı yatırım mevzuatı gibi, yatırım alanında akdedilmiş milletlerarası sözleşmelere ev sahibi ülkenin taraf olmasının da yabancı yatırımların teşvikindeki rolü tartışllmazdır.

Bu bağlamda gelişmekte olan ve yabancı yatırımlara ihtiyaç duyan Türkiye ve Kazakistan'ın, ülkelerine yabancl yatırımları çekmek amacıyla, yatırım mevzuatlarında zaman zaman değişikliğe giderek, yabancı yatırımları teşvik edici esaslara yer verdikleri görülmektedir. Nitekim yoğun olarak gerçekleştirilen yatırımların her iki ülkenin gelişmesinde önemli rol oynayacağı şüphesizdir.

\section{Anahtar Kelimeler}

Türkiye, Kazakistan, yabancı yatırım, yatırımın teşviki, milletlerarası sözleşmeler

* $\quad$ Bu çalışma, Dokuz Eylül Üniversitesi Sosyal Bilimler Enstitüsü Özel Hukuk Anabilim Dalında 2005 yılında savunulmuş "Türk ve Kazak Hukukunda Yabancı Sermayeli Şirketlerin Kuruluşu” başlıklı doktora tezinden üretilmiştir.

** Atatürk Üniversitesi Hukuk Fakültesi, Milletlerarası Özel Hukuk Anabilim Dalı Öğretim Üyesi (e-posta: s.ganiyeva@atauni.edu.tr) (ORCID: 0000-0002-9306-485X) (Makalenin Geliş Tarihi: 23.10.2018) (Makalenin Hakemlere Gönderim Tarihleri: 24.10.2018-25.10.2018/Makale Kabul Tarihleri: 10.02.2019-20.02.2019) 


\title{
INDUCEMENT OF FOREIGN INVESTMENT IN TURKISH AND KAZAKH LAWS
}

\begin{abstract}
Insufficiency of internal resources of developing countries creates need of recalling of external investment tools to the country.

Many developing countries proposes tax and inducement pack to the foreign investors in order to provide exterior resources and technology needed during development process. However, being applied of just these methods fall behind in recalling foreign investments. Because, foreign investors have to consider factors like economic and political stability, sufficient potential demand, accession to the raw material and opportunity of effective producing of the invested country while deciding to invest in another country.

Moreover, and maybe most significantly, in order to establish secure investment environment, it is unarguable that host country's being part of conventions which are internationally signed such as moderate investment regulations play a big role in inducement of foreign investments.

In this regard, it has been observed that Turkey and Kazakhstan, which are both developing countries and need foreign investments, allow for rudiments to promote foreign investments by changing investment regulations at times in order to attract investments. Hence, it is undoubted that promoting investments and intensive investments made right after will play a significant role in the development of the two countries.
\end{abstract}

\section{Keywords}

Turkey, Kazakhstan, foreign investment, investment inducement, international conventions 


\section{GİRIŞ}

Küreselleşen dünyada yabancı yatırımların önemi gün geçtikçe artmaktadır ve günümüzde hemen hemen tüm ülkeler, özellikle de gelişmekte olanlar, yabancı yatırımları çekme gayreti içerisindedirler. Zira "gelişmekte olan ülkelerin ekonomik sorunlarının başında sermaye yetersizliği gelmektedir. Bundan dolayı, ekonomideki bu kaynak açı̆̆ dış kaynak ihtiyacını zorunlu kılmakta ve bu ihtiyacın hibeler, krediler ve doğrudan sermaye yatırımlar ile sağlanmast yoluna gidilmektedir" ${ }^{\prime \prime}$.

Ancak belirtmek gerekir ki, günümüzde kaynak ihtiyacı yalnız gelişmekte olan ülkelerin sorunu olmayıp, gelişmiş ülkelerin de üzerinde önemle durdukları bir konudur. Hatta doğrudan yabancı yatırımların ağırlıklı olarak gelişmiş ülkelere yapıldığı da bir gerçektir. Zira yabancı yatırımcı, aradığ güven unsurunun gelişmiş ülkelerde daha sağlam olduğu düşüncesiyle hareket etmektedir ${ }^{2}$. Nitekim gelişmiş ülkelerde ekonomik ve politik bakımından istikrarın söz konusu olduğu, ekonomik ve siyasal hayatta büyük dalgalanmaların görülmediği ve dolayısıyla, güven verici bir ortamın her şeye hâkim olduğu görülmektedir ${ }^{3}$.

Bununla birlikte, tüm ekonomik ve siyasal ilişkilerde olduğu gibi, yabancı sermaye ${ }^{4}$ ilişkilerinde de asıl olan ülkelerin karşılıklı çıkar dengesinin kurulmasıdır. Yabancı sermayenin getirdikleri ile götürdükleri konusunda karşılaştırmalar da bu dengenin önemini ortaya çıkarmaktadır. Yabancı sermayeyi kabul edecek ev sahibi ülkenin, yabanc1 sermayeyi kabul etmeden önce, ekonomik stratejilerini iyi çizmesi ve bilinçli olarak fayda ve zarar analizlerini çok iyi yapması gerekmektedir ${ }^{5}$. Zira yabancı yatırımcıların bir ülkeye yatırım yapmasında, o ülkenin ekonomisine katkıda bulunmak ve kalkınmasına hizmet etmek gibi gayelerinin söz konusu olmadığ ${ }^{6}{ }^{6}$ ve sırf

\footnotetext{
Çelikel, Aysel/Öztekin Gelgel, Günseli: Yabancılar Hukuku, 20. Bası, BETA, İstanbul, 2014, s. 173.

2 Çelikel/Öztekin Gelgel, s. 173.

3 Karluk, S. Rıdvan: Türkiye'de Yabancı Sermaye Yatırımları (Yabancı Sermaye Yatırımları), Taştan Matbaası, İstanbul, 1983, s. 213.

4 "Yabancı yatırımlar" ile "yabancı sermaye" aynı anlam taşıdığından, çalışmamızda her iki kavrama da yer verilmiştir.

5 Karakoyunlu, Erdoğan: Türkiye'de Yabancı Sermaye Yatırımları ve Yabancı Sermaye Dairesinin 1980 Faaliyetleri Sonuçları, İstanbul, 1981, s. 10; Karluk, Yabancı Sermaye Yatırımları, s. 212; Hacaloğlu, Tuncay: Yabancı Sermaye ve Türkiye'de Yabancı Sermaye Uygulaması, Uzmanlık Tezi, Başbakanlık DPT Müsteşarlığı, Ankara, 1983, s. 3.

6 Karluk, Yabancı Sermaye Yatırımları, s. 210; Özel, Sibel: "Doğrudan Yabancı Yatırımlar Kanunu Üzerine Bir Değerlendirme”, Prof. Dr. Gülören Tekinalp’e Armağan, MHB, Y11: 23, 2003, s. 599.
} 
ticari çıkarlarını maksimize etmek için geldiklerinden dolayı, yabancı sermaye ile olan ilişkinin "karşılıklı çıkar" ilişkisi olduğunu göz önünde bulundurmak gerekmektedir ${ }^{7}$. Kaldı ki bazı yazarlarca, yabanc1 yatırımın ev sahibi ülke üzerindeki etkilerinin yalnızca olumsuz ve sömürücü nitelikte olduğu da savunulmuştur ${ }^{8}$.

Hirschman'a göre, doğrudan yabancı yatırımların ülkenin ekonomik kalkınmasının ilk dönemlerinde mevcut olmayan üretim faktörlerini ülkeye getirdiği için yararlı olduğu bir gerçektir. Fakat ülke geliştikçe yabancı yatırımların kalkınma ile birlikte gelişen mahalli faktörleri kullanmadığı ve mahalli teşebbüslere engel teşkil ettiğinden dolayı, ülkenin ekonomik büyümesini de genel anlamda engellemektedir ${ }^{9}$. Buna karşın diğer bir görüş ise yabancı özel teşebbüsün gelişmekte olan ülkelerin ekonomik kalkınmasında önemli bir rol oynadığını ve bu kalkınmayı hızlandırdığını savunmaktadır ${ }^{10}$.

Doktrindeki farklı görüşlere rağmen, az gelişmiş ve gelişmekte olan ülkelere yabancı yatırımların gelmesi, bu ülkeler bakımından büyük önem taşımaktadır. Ancak bunun için de yabancı yatırımların teşvik edilmesi gerekmektedir.

Nitekim gelişmekte olan ülkeler olarak Türkiye ve Kazakistan, doğrudan yabancı yatırımlarına ihtiyaç duymaktadır. Bugüne kadar her iki ülkeye de yabancı yatırımlar yapılmasına rağmen Türkiye, Kazakistan'a nazaran, yabanc1 yatırımlar bakımından daha tecrübelidir, zira yabanc1 yatırımların tarihsel başlangıcı Osmanlı Devleti'ne kadar uzanmaktadır ${ }^{11}$. Oysaki Kazakistan Cumhuriyeti, genel anlamda, yabanc1 yatırımlar ile Sovyetler Birliği'nin dağılmasından sonra karşılaşmışıır ${ }^{12}$.

Günümüzde yabancı yatırımlara duyduğu ihtiyaç sebebiyle Türkiye ve Kazakistan, yatırımların teşviki için çeşitli çalışmalarda bulunmaktadır.

7 Karluk, Yabancı Sermaye Yatırımları, s. 210.

8 Ayrıntılı bilgi için bkz Öztekin, Basri: "Yabancı Sermaye Hakkında Görüşler", İstanbul, YASED Yayınları No. 3, 1982.

9 Hirschman, A. O.: "How to Divest in Latin American and Why", Essays in İnternational Finance No: 76, Princeton University Press, November 1969, s. 5-9, (naklen Karluk, s. 23).

10 Streeten, P.: "New Approaches to Private Investment in Less Developed Countries", s. 436 (naklen Karluk, s. 23).

11 Ayrıntılı bilgi için bkz. Karluk, Yabancı Sermaye Yatırımları, s. 39 vd.

12 Paramonov, V. V.: Экономика Казахстана; Экономика, Рынок, Финансы (Ekonomika Kazakhstana; Ekonomika, Rınok, Finans1) (1990-1998), Almat1, G11ım, 2000, s. 5-6; Kazakistan Cumhuriyeti Türkiye Büyükelçiliği, Türkiye Cumhuriyeti İşadamları için Tanıtım Kılavuzu, Ankara, 1997, s. 12. 
Çalışmaların başında da her iki ülke bakımından ılımlı yatırım mevzuatının kabulü ile yatırım alanında akdedilmiş milletlerarası sözleşmelere taraf olmak gelmektedir.

$\mathrm{Bu}$ çerçevede aşağıda Türkiye ve Kazakistan Cumhuriyetlerinde yabanc1 yatırımların teşvikine yönelik yasal düzenlemeler ile birlikte yabancı yatırımcılara sağlanan milletlerarası güvencelere de yer verilecektir.

Fakat esas konuya geçmeden önce, yabancı yatırımın tanımı ile sınıflandırılmasına değinmenin uygun olacağı kanaatindeyiz.

\section{YABANCI SERMAYE YATIRIMLARININ TANIMI VE SINIFLANDIRILMASI}

\section{A. Yabancı Sermaye Yatırımlarının Tanımı}

Yabancı yatırımdan bahsedebilmek için üç temel unsurun varlığı gerekmektedir; bunlardan birincisi, yatırımcıdır (gerçek veya tüzel kişi); yatırımcının temel amacı ise kâr elde etmektir ${ }^{13}$. Diğer iki unsurdan biri, yatırımc1nın kendi ülkesi dışında yatırım faaliyetinde bulunduğu ev sahibi devlet ve diğeri de yatırımcının tâbi olduğu kaynak devlettir ${ }^{14}$.

Yabancı yatırımlar için farklı ayırımlar yapılmış olsa da ${ }^{15}$, daha ziyade doğrudan ve dolaylı (portföy) yatırım ayrımına dikkat çekilmektedir.

Yabancı yatırım kavramı uluslararası hukukta yeknesak bir şekilde tanımlanmamış olsa da, bu kavramın tanımı, genellikle, konu ile ilgili iki taraflı ve bölgesel anlaşmalarla yapılmaktadır ${ }^{16}$.

Bununla birlikte, yabancı yatırımlar ile ilgili doktrinde de farklı tanımlara rastlanmaktadır. Bir tanıma göre, yabancı sermaye yatırımları, genel anlamıyla ticari kazanımlar gözetilerek, sermaye fonlarının bir ülkeden diğerine hareketini ifade etmektedir ${ }^{17}$. Bir başka tanıma göre ise yabancı yatırım,

13 Reuber, G. L., Private Foreign Investment in Development, Oxford, 1973, s. 69 (naklen

Tiryakioğlu, Bilgin: Doğrudan Yatırımların Uluslararası Hukukta Korunması,

Dayınlarlı Hukuk Yayınları, Ankara, 2003, s. 9).

14 Tiryakioğlu, s. 9.

15 Örneğin, kamu yatırımları ve özel yatırımlar, sanayî yatırımları ve ticari yatırımlar vb.,

Tiryakioğlu, s. 9.

16 Tiryakioğlu, s. 9.

17 Karluk, Yabancı Sermaye Yatırımları, s. 14; Uludă̆, Ramazan: Türkiye'de Yabancı Sermaye Uygulamas1, Atıf Matbaacilık, Ankara, 1991, s. 23; "700 Firma 1,5 milyar \$ Yatırım” Ekonomik Forum Dergisi, Cilt: 5, Say1: 6, Haziran 1998, s.12; Sornarajah, M, İnternational Law, s. 4 (naklen Tiryakioğlu, s. 10; Богатырев А. Г.: Инвестиционное Право (İnvestitsionnoe Pravo), Rossiyskoe Pravo Yayınevi, Moskova, 1992, s. 13. 
dış kaynaklardan elde edilen ve sonradan ödenmek üzere bir ülkenin, ekonomik açıdan gelişmesi için temin ettiği mali ve diğer kaynaklardır ${ }^{18}$. Diğer yazarlar ise, en geniş anlamıyla yatırımları, finansal büyüme ve ülke ekonomisinin gelişmesini sağlayan mekanizma olarak tanımlamaktadır ${ }^{19}$. Yine bir başka yazara göre, yabancı yatırım; "taşınır veya taşınmaz varlıkların bir ülkeden başka bir ülkeye, bu varlıkların sahibinin klsmen veya tamamen denetimi altında, o ülkenin refahını arttırmak için kullanımı amacıyla transferi" olarak tanımlanmıştır ${ }^{20}$.

Ancak daha geniş bir tanıma göre doğrudan yabancı sermaye yatırımı, "bir ülkede bir firmayı satın almak veya yeni kurulan bir firma için kuruluş sermayesini sağlamak veya mevcut bir firmanın sermayesini arttırmak yoluyla o ülkede bulunan firmalara yapılan ve kendisiyle birlikte teknoloji, işletmecilik bilgisi ve yatırımcinın kontrol yetkisini de beraberinde getiren yatırımdır",21.

Son olarak, yalnızca dolaylı (portföy) yatırımları karakterize eden bir tanıma bakıldığında, dolaylı yatırımların, "sahibinin aktif yönetimi veya kontrolünü gerektirmeyen menkul klymet ve diğer malî varlıkların pasif olarak elde bulundurulması "22 seklinde tanımlandığı görülmektedir.

\section{B. Yabancı Sermaye Yatırımlarının Sinıflandırılması}

Yabancı sermaye yatırımları, genellikle, doğrudan yatırım veya portföy yatırımı şeklinde gerçekleşmektedir. Portföy yatırımları özel mali sermaye hareketi niteliğinde olmakta ve bir ülkedeki şirketlere ait hisse senedi ve tahvillerin o ülke sermaye piyasasından veya uluslararası sermaye piyasala-

18 Açıkalın, Sezgin/Ünal, Seyfettin: Doğrudan Yatırımlar ve Portföy yatırımları, Global ve Yerel Faktörlerin Türkiye Üzerindeki Göreceli Etkisi, Ekin Yayınevi, Bursa, 2008, s. 6.

19 Ovchinnikov, A. A/Gushin, V. V.: Инвестиционное Право. Учебник (İnvestitsionnoe Pravo. Uchebnik), Эксмо Yayınevi, Moskova, 2009, s. 11.

20 Sornarajah, M., The International Law on Foreign Investment, Cambridge, 1996, s. 4 (naklen Tiryakioğlu, s. 10).

21 Karluk, Yabancı Sermaye Yatırımları, s. 14; Karluk, S. Rıdvan: Uluslararası Ekonomi (Ekonomi), Beta, 5. Bas1, İstanbul, 1998, s. 399; Kayıhan/Eski’ye göre, "Yabancı doğrudan yatırımlar, portföy yatırımı dışında kalan ve yatırımcının sürekli (ör.yavru şirket kurarak) veya belli bir süre (ör.joint venture ortaklığı) yatırım ülkesinde faaliyetini sağlayan yatırımlardır”; Kayıhan, Şaban/Eski, Mehmet: Uluslararası Ekonomi Hukuku, Seçkin Yayıncılık, Ankara, 2010, s. 76.

22 Ovchinnikov/Gushin, s. 116; Turanlı, Hüsnü: Doğrudan Yabancı Yatırımların Hukuki Çerçevesi, Gazi Üniversitesi Sosyal Bilimler Enstitüsü Özel Hukuk Anabilim Dalı, yayınlanmamış doktora tezi, 2008, s. 11. 
rından dışarıda yerleşik kişi ve kuruluşlarca satın alınması yoluyla yapılmaktadır. Doğrudan yatırımlar ise reel bir nitelik taşımakta ve yabancı ülkelerde bina, fabrika, arazi, tesis gibi fiziki değerler elde edilmesi şeklinde yapılmaktadır $^{23}$. Yani, doğrudan yabancı yatırım, taşınır veya taşınmaz varlıkların bir ülkeden başka bir ülkeye, bu varlıkların sahibinin kısmen veya tamamen denetimi altında o ülkenin refahını artırmak için kullanımı amacıyla transferidir $^{24}$.

Doğrudan yatırımlar, portföy yatırımlarından farklı olarak, sermaye ile birlikte teknoloji ve işletmecilik bilgisini de beraberinde getirmektedir. $\mathrm{Bu}$ nedenle özellikle II. Dünya Savaşı'ndan sonra yabancı sermaye hareketleri içinde doğrudan yatırımların payı ve önemi büyük ölçüde $\operatorname{artmıştır~}^{25}$.

Doğrudan yatırım, geldiği ülkeye teşebbüs, teknoloji, risk taşıma ${ }^{26}$ ve organizasyon aktarımı sağlamakta ve bu sebeple işletmelerin sadece kuruluş ve teçhizatın finansmanı olarak değerlendirilmemektedir. Bunun yanı sıra doğrudan yatırım, bu rolünden dolayı işletmecilik ustalığ1 ve know-how'u da beraberinde getirerek, ayrıca, rekabet faktörünü de ülkeye sokmaktadır ${ }^{27}$.

Günümüzde doğrudan yabancı sermaye yatırımlarının önemli bir bölümü çok uluslu şirketler ${ }^{28}$ tarafından gerçekleştirilmektedir. Bunlar, belli bir merkezden yönetilen ve aynı anda çeşitli dünya ülkelerinde üretimde bulunan dev firmalardir ${ }^{29}$.

Yukarıda belirtilmiş olan hususlar, doğrudan yabancı sermaye yatırımları ile dolaylı ya da portföy yatırımları arasındaki en önemli farkları ortaya koymakla birlikte, bunlarla da sınırlı değildir.

23 Seyidoğlu, Halil: Uluslararası İktisat, Güzem Yayınevi, İstanbul 1994, s. 577.

24 Tiryakioğlu, s. 10.

25 Karluk, Ekonomi, s. 399.

26 Dolaylı yatırımcı, bir risk gördüğünde, yatırımını derhal çekebilir ve diğer portföy yatırımlarına transfer edebilir. Doğrudan yabancı yatırımcının ise böyle bir imkânı yoktur. Zira yabancı yatırımcı ev sahibi ülkeyi hemen terk edemez; Çelikel/Öztekin Gelgel, s. 174; Tiryakioğlu, s. 11.

27 Karluk, Yabancı Sermaye Yatırımları, s. 14-15.

28 Çok uluslu şirketler yatırım yaparken, küresel bir strateji izledikleri için, bu tür yatırımlarda denetim unsuru giderek daha önemli olmaya başlamıştır. Kendi yatırımını güvence altına almak için çok uluslu şirketin kullanabildiği güç dikkat çekicidir ve böyle bir gücün varlığı, uluslararası düzeyde bu şirketin denetimine ilişkin talepleri gündeme getirmektedir. Bu durum dolaylı yatırım bakımından söz konusu değildir. Tiryakioğlu, s. 11.

29 Çelikel/Öztekin Gelgel, s. 175; Seyidoğlu, s. 577; Tiryakioğlu, s. 11; Alpar, Cem: Çok Uluslu Şirketler ve Ekonomik Kalkınma, Turhan Kitabevi, Ankara, 1980, s. 35. 


\section{TÜRKIYY VE KAZAKISTAN'DA ULUSAL DÜZEYDE YABANCI YATIRIMLARIN TEŞVİKI}

\section{A. Türk ve Kazak Hukukunda Yabancı Yatırımların Düzenlenmesi}

\section{Türk Hukukunda}

Türk hukuku her çeşit iş kolu için yabancı yatırımlara ${ }^{30}$ açıktır. Yabancı yatırımcı hangi alana yatırım yapıyorsa, o sektörü düzenleyen hukuk kuralları yabancı yatırıma ilişkin mevzuat ile birlikte uygulanmaktadır. Örneğin, turizm, maden, petrol ve diğer alanları düzenleyen yasalar, yabancı yatırımları düzenleyen mevzuat ile birlikte değerlendirilecektir ${ }^{31}$.

Türkiye'de yabancı yatırımlar 5 Haziran 2003 tarihli ve 4875 sayılı Doğrudan Yabancı Yatırımlar Kanunu (DYYK) ${ }^{32}$ ile düzenlenmiş ve konu ile ilgili Ağustos 2003 yılında Doğrudan Yabancı Yatırımlar Kanunu Uygulama Yönetmeliği (Yönetmelik) ${ }^{33}$ kabul edilmiştir.

Ancak yabancı yatırım mevzuatının temel kaynağını 1982 tarihli Türkiye Cumhuriyeti Anayasas ${ }^{34}$ teşkil ettiği için, öncelikle, Anayasa'da yer alan esaslara değinilecektir.

\section{a. Anayasa}

Anayasa, iç hukuk kaynaklarının en önemlisidir ve Anayasada yabanc1ların hukuki durumunu düzenleyen hükümlerin bulunması mümkündür. Konu ilk olarak 1961 Anayasasına $^{35}$ girmiş ve daha sonra aynı hüküm 1982 Anayasasında da yer almıştır ${ }^{36}$.

Dünyada, yabancıların hukuki durumuyla ilgili iki sistem mevcuttur:

1. Eşitlik sistemi,

2. Yabanciların haklarını sinırlayan sistem.

Türk Hukukunda, kural olarak, eşitlik sistemi kabul edilmiştir ${ }^{37}$. Anayasanın 10. maddesine göre: "Herkes dil, ırk, din, cinsiyet, siyasi düşünce,

30 Burada önemle belirtmek isteriz ki, çalışmamızdaki yabancı yatırım tabiri ile kastedilen doğrudan yabancı yatırımlardır.

31 Çelikel/(Ö̈tekin) Gelgel, s. 175.

32 RG: 17.06.2003-25141. Bundan sonra kısaca 4875 say11 DYYK olarak anılacaktır.

3 RG: 20.08.2003-25205. Bundan sonra kısaca Yönetmelik olarak anılacaktır.

34 RG: 09.11.1982-17863 (Mükerrer).

35 RG: 20.07.1961-10859.

6 Çelikel/(Öztekin) Gelgel, s. 51.

37 Göğer, Erdoğan: Yabancılar Hukuku, Sevinç Matbaası, 3. Bası, Ankara, 1979, s. 21 vd. 
felsefi inanç ve mezhep ayrımı gözetmeksizin, kanun önünde eşittir" denilmektedir. Benzer mahiyette hüküm Anayasanın 48'inci maddesinde düzenlenmiştir. Şöyle ki: "Herkes dilediği alanda çalışma ve sözleşme hürriyetlerine sahiptir. Özel teşebbüsler kurmak serbesttir. Devlet özel teşebbüslerin milli ekonominin gereklerine ve sosyal amaçlara uygun yürümesini, güvenlik ve kararlılık içinde çalışmasını sağlayacak tedbirler alır".

Ancak Anayasa, bazı sınırlamalar getirilmesi gerektiğini de dikkate alarak, vatandaş ve yabancıya eşit haklar tanıyan bu hükümleri 16. madde ile sınırlandırmıştır. Anayasanın bahsi geçen maddesi, "temel hak ve hürriyetleri yabancılar için milletlerarası hukuka uygun olarak kanunla sinırlanabileceğini" hüküm altına almıştır. Ancak devlet, vatandaş ile yabancı arasındaki eşitliği ${ }^{38}$ bozarken milletlerarası hukuka ${ }^{39}$ uygun hareket etmelidir.

Ayrıca, Anayasanın 16. maddesi uyarınca, yabancılar bakımından yapılacak düzenleme ve sınırlamalar, yasama organının çıkardığı kanunlarla belirlenmelidir. Kararname, yönetmelik, tebliğ veya genelge yolu ile yapılan sınırlayıcı düzenlemelerin bir yasayı temel almaları esastır ${ }^{40}$. Buna karşın bazı yazarlar, anılan maddedeki kanun kavramının hukuk anlamında olduğunu ve bu nedenle yürütmenin düzenleyici işlemlerle getirdiği sınırlamaların 16. maddeye aykırı düşmeyeceğini savunmaktadır. Nitekim bu görüşe göre, sınırlayıcı işlemlerin herhangi bir kanun hükmüne dayanmasının gerekli olmadığı da vurgulanmaktadır ${ }^{41}$.

Yabancılara ilişkin tüm sınırlamalara rağmen, bir yabancı, diğer ülkede yaşama ve çalışma olanağı edinebilmekte ve insan olarak onuru korunmaktadır. Söz konusu farklar ister özel haklar, ister kamu hakları alanında olsun, insanın insan olma onuruna yakışır şekilde yaşama olanağını zedeler nitelikte ve nicelikte değildir. Kısıtlamalar daha çok kamu sağlı̆̆ı ve güvenliği ile kamu düzeni alanındadır ${ }^{42}$.

38 Tekinalp'e göre, yabancılar hukukunda tam bir eşitlik söz konusu değil, hatta bazı hallerde eşitlik yetersiz kalabilir. Bu durumda, yazara göre, eşitlik ilkesini yabancilar hukukunda vazgeçilmez olarak kabul etmek yerine yararlı olduğu oranda ele almak ve değerlendirmek yerinde olabilir; Tekinalp, Gülören: Türk Yabancılar Hukuku, Beta, 8. Bası, İstanbul, 2003, s. 26.

39 Milletlerarası hukuka uygun sınırlamalarda, milletlerarası sözleşmeler, milletlerarası örf ve adet ve yardımcı kaynak olarak da milletlerarası mahkeme kararları göz önüne alınabilecektir, Çelikel/Öztekin Gelgel, s. 59.

40 Çelikel/(Öztekin) Gelgel, s. 59.

41 Göğer, s. 41; Ökçün, A. Gündüz: Yabancıların Türkiye'de Çalışma Hürriyetleri, Doğuş Matbaacılık ve Ticaret Limited Şirketi Matbaası, Ankara, 1962, s. 80.

42 Tekinalp, s. 26. 
Yabancılarla ilgili önemli konulardan bir diğeri de uyuşmazlıkların çözümüdür. Uyuşmazlıkların çözümünü düzenleyen hüküm, Anayasanın 125 'inci maddesinde "yargı yolu" başlığı altında yer almaktadır. Madde hükmüne göre: “...Kamu hizmetleri ile ilgili imtiyaz şartlaşma ve sözleşmelerinde bunlardan doğan uyuşmazlıkların milli veya milletlerarası tahkim yoluyla çözülmesi öngörülebilir. Milletlerarası tahkime ancak yabancılık unsuru taşıyan uyuşmazlık için gidilebilir". 1999 tarihli ve 4446 sayılı Türkiye Cumhuriyeti Anayasasının Bazı Maddelerinde Değişiklik Yapılmasına İlişkin Kanunun ${ }^{43}$ 2.maddesi ile Anayasanın 125'inci maddesine eklenen yeni hükümle Türkiye'nin, bugüne kadar yapmış olduğu çeşitli uluslararası sözleşmelerde kabul etmiş olduğu esaslara uygun olarak, kamu hizmetleri ile ilgili imtiyaz şartlaşma ve sözleşmelerinden doğan uyuşmazlıkların milli veya milletlerarası tahkim yoluyla çözülmesi öngörülmüştür.

Nitekim Anayasada yer alan genel ilkeler doğrultusunda kanun koyucu, yabanc1 yatırımları düzenleyen 4875 sayılı Kanunu kabul etmiştir. Ancak bu Kanun, konu ile ilgili ilk yasal düzenleme olmadığından, aşağıda yatırım mevzuatının tarihçesine de kısaca değinmenin yararlı olacağ 1 düşüncesindeyiz.

\section{b. Türkiye'de Yatırım Mevzuatının Tarihçesi}

Osmanlı İmparatorluğu döneminde yabancı şirketlerin 19. yüzyıldan itibaren yatırım yaptıkları görülmektedir. Fakat yabancı şirketler mal üretimine yönelmeyip, demiryolları, denizyolları, limanlar, tramvay, tünel, havagazı, elektrik ${ }^{44}$ gibi hizmet üretimine monopol biçimde yatırım yapmayı tercih edip, uzun yıllar bu alanlarda faaliyette bulunmuşlardır. Lozan Antlaşması ile kapitülasyonların kaldırılmasının ardından, yabancılarla yapılan ikili sözleşmelerle yabancı şirketlerin bu hizmetlerine son verilmiş ve borçların ödenmesi de 1950'li yıllara kadar süren dönem içinde vadelere bağlanmıştır. $\mathrm{Bu}$ dönem içinde yeni yabancı yatırım yapılmamış, zira hem devlet hem de Türk halkı, tarihsel koşullar nedeniyle, yabancı yatırıma karşı olumsuz tutum sergilemiştir ${ }^{45}$.

$43 \quad$ RG: 14.08.1999-23786.

$44 \mathrm{http} / / /$ www.ekodialog.com/osmanli_ekonomisi/osmanli-devletinde-yabancisermaye.html, Erişim tarihi 12.02.2018.

45 Çelikel/Öztekin Gelgel, s. 175-176; Bozdağlığlu, Yasemin/Evimoğlu, Umut: “Türkiye'de Doğrudan Yabancı Sermaye Yatırımlarının Tarihsel Süreçte Gösterdiği Gelişim: Hukuksal ve Ekonomik Yansımaları", Dicle Üniversitesi Sosyal Bilimler Enstitüsü Dergisi, Nisan, 2014, Y11-6, S: 11, 3. 35-36; Ayrıca ayrıntılı bilgi için bkz. Karluk, Yabancı Sermaye Yatırımları, s. 39 vd. 
Ancak 1950 yılında çok partili sisteme geçilince, Türk ekonomisinde de bazı değişikliklere gidilmesi düşünülmüş ve bu açıdan yabancı sermayenin de yeniden ülkeye çekilmesi gündeme gelmiştir. Bu amaçla da 1951 tarihinde 5821 sayılı Yabancı Yatırımları Teşvik Kanunu ${ }^{46}$ kabul edilmiş ve maden, bayındırlık, ulaştırma, turizm gibi alanlar yabancı sermayeye açılmıştır. Kanun ile yabancı yatırımcıların yurt dışına kâr transferleri \%10 ile sınırlanacağı ve yıllık kârın bu miktarı aşması halinde kalan miktarı, \%10 kârın gerçekleşmediği y1llara ekleneceği kabul edilmiştir. 5821 sayılı Kanun'un yabanc1 yatırımcılar tarafından cazip görülmemesi üzerine, 1954 yılında 6224 sayılı Yabancı Sermayeyi Teşvik ${ }^{47}$ Kanunu (YSTK) ${ }^{48}$ çıkarılmıştır ${ }^{49}$.

Aslında YSTK'nın doğrudan yabancı yatırımlar için gerekli yasal altyapıyı sağlaması ve dönemin oldukça liberal düzenlemesi olmasına rağmen, yabanc1 sermayeden pek ilgi görmemiş ve yabancı sermayenin gelişinde belirgin bir artış sağlanamamıştır. Yabancı sermayenin bu denli yetersiz düzeyde kalmasının en önemli nedeninin ekonomik ve siyasi istikrarsızlık, terör olayları, kâr transferindeki aksamalar, başvuruların sonuçlandırılmasına kadar uzun ve yorucu bir bürokrasinin hâkim olduğunu söylemek mümkün olmaktadır. Ayrıca, Kanunun yürürlüğe girdiği tarihten itibaren doğrudan yatırımlara ilişkin ortaya çıkan kavram ve uygulama farklılıkları ve yatırımcıların haklarını uluslararası standartlarda korumadaki eksikliği, ülkeye yabancı yatırımların yapılmasını olumsuz yönde etkilemiştir ${ }^{50}$.

Ancak 6224 sayılı YSTK'nın yürürlükte kaldığı zaman içerisinde siyasi ve ekonomik hayatta yaşanan gelişmeler ile mevzuatta yapılan değişiklik$1 \mathrm{er}^{51}$, yeni bir düzenlemeyi ihtiyaç haline getirmiştir. Nitekim 2003 yılında

46 RG: 09.08.1951-7880.

47 Yasanın isminde "Teşvik" ibaresinin yer almasının nedeni ise, o yıllar için teşvik unsuru olarak kabul edilebilecek kâr transferi, eşit muamele gibi hususları içermesi idi. Ancak yasanın yürürlükte kaldığı yaklaşık yarım asırlık zaman dilimi içerisinde, ekonomik hayatta yaşanan gelişmeler ve ilgili mevzuatta yapılan değişiklikler, söz konusu hususların teşvik aracı yerine, genel kabul görmüş uluslararası yatırım ilkelerine dönüşmesine neden olmuştur. $\mathrm{Bu}$ nedenle uluslararası tanımlamalara da uygun olarak yeni yasanın ismi "Doğrudan Yabancı Yatırımlar Kanunu" olarak belirlenmiştir; Özel, s. 600; Yabancı Sermaye Raporu, Temmuz, 2003, Hazine Müsteşarlı̆̆ı, YSGM, Ankara. RG: 23.01.1954-8615. Bundan sonra kısaca YSTK olarak anılacaktır.

Çelikel/Öztekin Gelgel, s. 176.

50 Çelikel/Öztekin Gelgel, s. 176; Karluk, Yabancı Sermaye Yatırımları, s. 127; Bozdağlıoğlu/Evimoğlu, s. 42 .

511980 sonrası Türkiye'nin ekonomisinin dışa açılarak, ihracatı teşvik eden serbest politikaların uygulanması, 24 Ocak tarihli 8/168 Sayılı "Yabancı Sermaye Çerçeve Kararnamesi" (YSÇK) ve bu Kararname ile doğrudan Başbakanlığa bağlı olarak kurulan 
4875 sayılı DYYK kabul edilerek 6224 sayılı Kanun'u yürürlükten kaldırmıştır.

\section{c. Doğrudan Yabancı Yatırımlar Kanunu}

Doğrudan yatırımlara ilişkin temel yasa olarak tasarlanan 4875 sayılı DYYK ile Türkiye'ye girişi bir türlü yeterli yoğunlukta sağlanamayan yabancı yatırımların özendirilmesi ${ }^{52}$ amaçlanmıştır (m.1). Bu amacın gerçekleştirilmesi için de yabancı yatırımcı haklarının güvence altına alınması ve bürokrasiyi ağırlaştıran izin sisteminin ${ }^{53}$ kaldırılarak yerine bildirim sisteminin $^{54}$ getirilmesi yoluna gidilmiştir ${ }^{55}$. Ancak doğrudan yatırımlar için

Yabancı Sermaye Dairesi'nin, Maliye, Ticaret, Sanayi ve Teknoloji Bakanlıkları ve Devlet Planlama Teşkilatı (DPT) tarafından verilen hizmetleri bünyesinde toplayarak, tüm yabanc1 yatırımcılara karşı tam yetki ile hizmet vererek bürokrasiyi azaltması, doğrudan yabancı yatırım girişlerini oldukça hızlandırırken, faaliyet gösteren yabancı sermayeli firmaların sayısının da büyük ölçüde artmasına neden olmuştur; Yılmaz, Cengiz: “Türkiye'de Yabancı Sermaye ve Kârlılık", Prof. Dr. Muammer Aksoy'a Armağan, Ankara, 1991, s. 476.

524875 sayılı Kanun kabul edildikten sonra genel olarak Türkiye'de yabancı yatırımlarda artış meydana gelmiştir; http://herdem.av.tr/tr/dorudan-yabanc-yatrmlar-ve-trkiye/ Herdem Hukuk Bürosu, İstanbul, Erişim 03.02.2018.

53 Yürürlükten kaldırılmış olan 95/6990 Sayılı Yabancı Sermaye Çerçeve Kararı (RG: 23.7.1995-22352) 1şı̆̆ında, Türkiye’ye sermaye getirilmesi ile ilgili izin, tescil, yatırım olanaklarından yararlandırma ve Karar'da belirtilen bütün işlemleri Hazine Müsteşarlığı Yabancı Sermaye Genel Müdürlüğü yürütmekteydi. Bahsettiğimiz Kararın madde 3’üne göre, Yabancı Sermaye Genel Müdürlüğünce verilen izinlerin kapsadığı esaslardan bazıları şunlar idi: a) Yurt dışında yerleşik kişi ve kuruluşların Türkiye'de yatırım yapmak ve/veya ticari faaliyette bulunmak amacıyla şirket kurma, ortaklığa katılma, şube ve irtibat bürosu açma müracaatları; b) Mevcut yabancı sermayeli şirketlerin; yeni yatırım, kapasite artışı, tasfiye ve birleşme, iştirak izinleri ve iştirak nispeti değişiklikleri ile mevzuatlarında belirtilen süre, miktar, ihracat taahhüdü, faaliyet alanı, değer, hisse nispeti gibi hususlara ilişkin değişiklik yapmak; c) Şirket kuruluşu, ortaklığa katılma ve şube açma durumlarında, yurt dışında yerleşik her biri kişi veya kuruluşun asgari 50.000 ABD Doları tutarında yabancı sermaye getirmeleri gerekmekteydi...

54 Kanunun getirdiği bu yenilik bazı yazarlarca eleştirilmiştir. Şöyle ki: "Kanun Tasarısı'nın getirdiği radikal değişiklik, Anayasa'da tanınan temel hakların kullanılmasında, yabancıların durumunun dikkate alınması ilkesini göz ardı eden bir düzenlemedir. Bunun dışında, izin sisteminin kaldırılması, yabancı yatırımlar konusunda idarenin bir planlama yapabilme olanağını da önemli ölçüde sınırlandırmaktadır. Ülke ekonomisi için yararlı olmadığı düşünülen bir doğrudan yabancı yatırımcıyı "izin vermeme" yoluyla engelleme olanağı bulunmamaktadır”. Dikmen, Ahmet Alpay/Karahanoğulları, Onur: "Doğrudan Yabancı Yatırımlar Kanunu Tasarısı Hakkında Değerlendirme", http://www.bilkent.edu.tr/ yeldanbs/Yazilar_Uye/DikmenKara.html; Gökyayla Demir ve Süral ise, bu eleştirilerin doğruluk payının bulunması yanı sıra, bunun bir siyasi ve ekonomik tercih olduğunu belirtmektedirler. Yabancıların yatırım yapmalarına izin 
izin alma zorunluluğun kalkmış olması, idarenin bu yatırımlarla hiç ilgilenmediği anlamına da gelmemektedir. Hazine Müsteşarlığının doğrudan yabanc1 yatırımlar konusunda politika belirleme yetki ve görevinin olduğu önemle belirtilmelidir. Hatta Müsteşarlık bu konuda istatistik amaçlı bir bilgi isteme sistemi kurma ve geliştirme yetkisine sahiptir (m.4). Yabancı yatırımcının da yatırımı ile ilgili istatistiki bilgileri Müsteşarlığa vermesi zorunludur (m.4).

Sonuç itibariyle, 4875 sayılı DYYK ile esas olarak Türkiye'nin uluslararası yatırımlara yönelik eşitlikçi ve liberal yaklaşımı yansıtılmakta ve Kanuna, "yatırımcıya açık ve anlaşılır mesajlar veren" ve yatırımcının değişik mevzuatlar gereği sahip olduğu haklar ve tabi olduğu yükümlülükleri gösteren yasal bir rehber niteliği kazandırılmaktadır ${ }^{56}$.

\section{d. Kanunda Yer Alan Esaslar}

\section{aa. Yabancı Yatırım ve Yabancı Yatırımcı Kavramı}

\section{aaa. Yabanct Yatırım}

4875 sayılı DYYK, doğrudan yabancı yatırımın yurt içinden veya yurt dışından temin edebilmesini öngörmektedir. Yurt dişından yapılan yatırım Türkiye Merkez Bankasında değiştirilebilir döviz, şirket menkul kıymetleri, makine ve teçhizat ve sınai veya fikri mülkiyet hakları olabilir (m.2/b (1)). Yeniden yatırımlarda kullanılan kâr, hasılat, para alacağı, yatırımla ilgili mali değeri olan diğer haklar ile doğal kaynakların aranması ve çıkarılmasına ilişkin haklar ise yurt içinden yapılan yatırım olarak kabul edilmektedir (m.2/b (2)).

verme yetkisinden vazgeçilmesi yoluyla yabancı yatırımlar bürokratik işlemlerden kurtarılmıştır. Amaç, bu sayede daha çok yabancı yatırımcıyı Türkiye'ye çekmektir. Bu da ülke ekonomisinin kalkınması bakımından siyasi ve ekonomik bir tercihtir. Yabanc1 yatırımların ülke ekonomisine katkıları düşünüldüğünde bu yönde bir tercih yapılmasının, katı bir denetim ve izin sistemine göre daha da ülke lehine olduğunu belirtmekte yarar vardır; Demir Gökyayla, Cemile/ Süral, Ceyda, “4875 Sayılı Doğrudan Yabancı Yatırımlar Kanunu ve Getirdiği Yenilikler”, Dokuz Eylül Üniversitesi Hukuk Fakültesi Dergisi, Cilt: 6, Say1: 2, 2004, s. 139.

55 Tekinalp, s.150; Çelikel/ (Öztekin) Gelgel, s. 180; Çelikel, Aysel, "Yabancı Yatırımların Teşviki Amacıyla Yapılan Yeni Yasal Düzenlemeler", Prof. Dr. Gülören Tekinalp'e Armağan, MHB, 423, S. 1-2, 2003, s. 165; Kılıçkaya, A. Hayati, "Yabanc1 Sermaye Yatırımı ile Yabancıların Türkiye'de Taşınmaz Edinimlerindeki Mevzuat Değişiklikleri”, Türk Hukuk Enstitüsü Dergisi, Eylül, 2003, s. 11; Kumkale, Rüknettin: Yabancı Sermayeli Şirketler, Seçkin Yayınevi, 2. Baskı, Ankara, 2003, s. 17.

56 Kumkale, s. 22. 
Görüldüğü üzere, eski mevzuatta ${ }^{57}$ çoğu mevcut olan yatırım imkânları daha açık bir sınıflandırmaya tabi tutulmuş ve bunlara yurt içindeki para alacakları da eklenerek daha da zenginleştirilmiştir. Böylece alacağın temlikinin yabancı sermayenin kaynağı olmasında ilk adım atılmıştır ${ }^{58}$.

\section{bbb. Yabancl Yatırımcl}

4875 sayılı DYYK'nın getirmiş olduğu en önemli yeniliklerden biri de, yabancı yatırımcı kavramının genişletilmesidir. Nitekim Kanun'un madde 2/a'ya göre, yabanc1 ülkelerin vatandaşlığına sahip olan gerçek kişiler ile yabanc1 ülkelerin kanunlarına göre kurulmuş tüzel kişiler ${ }^{59}$ ve uluslararası kuruluşların yanı sıra, yurt dışında ikamet eden Türk vatandaşları da yabancı yatırımcı olarak nitelendirilecektir.

O halde 4875 sayılı DYYK' da yatırımcıya ilişkin iki yenilik söz konusu olmaktadır. Birincisi, yabancı ülkede ikamet eden Türk vatandaşlarına da yatırım imkânının tanınmış olması (m. $2 / 1)^{60}$, ikincisi ise uluslararası kuruluşların da aynı hakka sahip olabilmesidir (m.2/2).

Doktrinde Türk vatandaşlarına ilişkin düzenlemenin yerinde olduğu vurgulanırken $^{61}$, ne tür uluslararası kuruluşların bu haktan yararlanacağının açık olmadığına da dikkat çekilmektedir ${ }^{62}$.

Ancak yurt dışında ikamet eden Türk vatandaşları, Yönetmeliğin 10. maddesine göre, yurt dışında ikamet ettiğini çalışma veya ikamet izni ile belgeledikleri takdirde, Kanunun uygulanması bakımından yabancı yatırımcı sayılacaklardır.

\section{bb. İzin Alma Zorunluluğunun Kaldırılması}

Daha önceki yabancı sermayeyi teşvik mevzuatından farklı olarak, bildirim sisteminin getirilmesi sonucunda, aynen Türkiye'de Türklerin kurduğu şirketler gibi yabancıların Türkiye'de Türk kanunlarına göre kurdukları şirketler de izin alınmaksızın yatırım faaliyetinde bulunabilmektedir (m.3/a (1)).

57 Bkz. mülga 6224 sayılı YSTK madde 2.

58 Tekinalp, s. 151.

59 Burada kanun her ne kadar tüzel kişiler tabirini kullanmış ise de bunun ticari ortaklıklar olarak algılanması yerinde olacaktır. Zira dernek ve vakıfların niteliği gereği yatırım faaliyetine girişmeleri söz konusu değildir; Özel, s. 603.

60 Mülga yabancı sermayeyi teşvik mevzuatına göre, yurt dışında ikamet eden Türk vatandaşlarının yatırımları yabancı sermaye kapsamına alınmamıştı; bkz. 1995 Tarihli 95/ 6990 Sayılı Yabancı Sermaye Çerçeve Kararı, m.2/b. (RG: 23.7.1995-22352).

61 Çelikel/(Öztekin) Gelgel, s. 180.

62 Tekinalp, s. 152. 
Ayrıca, Tekinalp'ın konu ile ilgili tespitini de yerinde bulmaktayız. Yazara göre, yabancı sermayeyi yoğun bir şekilde Türkiye'ye getirmek isteyen yeni sistemin mantığı doğrudur. Zira Türk kanunlarına göre Türkiye'de kurulan bir şirket zaten Türk şirketidir ve diğer Türk şirketlerinden farklı bir işleme tabi tutulmamalıdır. Yabancı şirketin şube açması halinde ise, eskiden olduğu gibi, Türk şirketlerinin kuruluş esasları uygulanacaktır. Bu noktada bir fark söz konusu değildir. Tek ve önemli fark, ayrıca izin alınmasının gerekmemesidir $^{63}$.

\section{cc. Yatırım Serbestisi ve Eşit Muamele}

4875 sayılı DYYK madde 3/1 uyarınca, yabanc1 yatırımcılar tarafindan Türkiye'de doğrudan yatırım yapılması serbesttir. Bu esas, 4875 sayıl1 Kanunu, mülga 1954 tarihli YSTK'dan ayıran en önemli kurallardan biridir. Önceki Yasanın ${ }^{64} \operatorname{arad}_{\text {ğ }}$ şartların oluşup oluşmadığının incelenmesi ve buna göre karar verilmesi esasını ortadan kaldırarak izin ve onay sisteminden bilgilendirme sistemine geçilmesi ile yabancı yatırımcıların önü açılmak istenmiştir $^{65}$.

Nitekim 4875 sayılı DYYK'nun 3/2. maddesinde doğrudan yabanc1 yatırımcıların yerli yatırımcılarla eşit muamele ${ }^{66}$ göreceği, Kanunda net bir şekilde ifade edilmiştir.

\section{dd. Transfer Serbestisi}

Yabancı yatırımcıların Türkiye'deki faaliyetlerinden doğan net kâr, temettü, satış, tasfiye ve tazminat bedelleri, lisans, yönetim ve benzeri anlaşmalardan doğan alacakları, dış kredi, anapara, faiz ödemeleri bankalar ve

\footnotetext{
63 Tekinalp, s. 153.

64 Çalışmamızda kanun kavramı yanı sıra yasa kavramına da yer verilmiştir.

65 Çelikel, s. 167.

66 Ancak bu esasa ilişkin de doktrinde eleştiri yapılmıştır. Dikmen ve Karahanoğulları'na göre, "yabancı yatırımcılara, uyruğu oldukları ülkelerde, Türk girişimcilere aynı hakkın tanınmış olmadığına bakılmaksızın, Türkiye'de yatırım serbestisi tanınmaktadır. Bu durum karşılıklılık ilkesine aykırıdır”. Dikmen/Karahanoğulları, http://www.bilkent. edu.tr/ yeldanbs/Yazilar_Uye/DikmenKara.html, Buna karşılık bizim de katıldı̆̆ımız diğer görüşe göre, doğrudan yabancı yatırımlar alanında karş1ılık esası aranmamıştır. $\mathrm{Bu}$ bir siyasi ve ekonomik tercihtir. Ekonomileri yabancı yatırımlara gereksinim duyan ülkeler aralarında yabancı yatırımcıyı kendi ülkesine çekmek için rekabet ettiklerinden, karşılıklılık ilkesinin aranması Kanun'un amacıyla bağdaşmazdı; Demir Gökyayla/ Süral, s. 140. Ayrıca, Türk yabancılar hukukunda, her hak karşılıklı muamele esasına dayanmaz. Karşılıklılık ilkesi açıkça kabul edilmediği alanlarda uygulanmaz; Çelikel/ (Öztekin) Gelgel, s. 61.
} 
özel finans kurumları aracılığıyla yurt dışına serbestçe transfer edilebilir (m. $3 / c)$.

Böyle bir garanti eski mevzuatta da $\operatorname{vard}^{67}$, ancak yeni metin ile bankalar yanında özel finans kurumlarına da transfer yetkisi verilerek, bu bakımdan doğrudan yabancı yatırımcıya kolaylık sağlanmıştır.

\section{ee. Taşınmaz Edinme}

4875 sayılı DYYK, yabancı yatırımcıların Türkiye'de kurdukları veya iştirak ettikleri tüzel kişiliğe sahip şirketlerin Türk vatandaşlarının edinimine açık olan bölgelerde taşınmaz mülkiyeti veya sınırlı aynı hak edinmelerine imkân tanımış idi (3/d), ancak bu hüküm, Anayasa Mahkemesi Kararı ${ }^{68}$ ile iptal edilmiştir.

Nitekim yabancıların Türkiye'de taşınmaz edinimleri' ${ }^{69} 2644$ sayılı 1934 tarihli Tapu Kanunu ${ }^{70}$ ile düzenlenmiştir.

Bahsi geçen Kanun'da 2012 y1lında 6302 sayılı Kanun ${ }^{71}$ ile yapılan son değişiklik ile yabancı gerçek ve tüzel kişiler ile yabancı sermayeli şirketlerin Türkiye'de taşınmaz edinme hakları düzenlenmiştir. Söz konusu yabancı gerçek kişilerin taşınmaz edinimi olunca, Kanunun 35/1. maddesine göre: “1) Kanuni sinırlamalara uyulmak kaydiyla, uluslararası ikili ilişsiler yönünden ve ülke menfaatlerinin gerektirdiği hallerde Bakanlar Kurulu ${ }^{72}$

67 Bkz. mülga 6224 sayılı YSTK (m. 4).

68 Anayasa Mahkemesi,11.03.2008 tarihli ve E: 2003/71, K: 2008/79 say1l Karar1; RG: 16.04.2008-26849. “... Dava konusu yasa kuralıyla yabancı yatırımclların Türkiye'de kurdukları veya iştirak ettikleri tüzel kişiliğe sahip şirketlerin Türk vatandaşlarının edinimine açık olan bölgelerde taşınmaz mülkiyeti veya sınırlı ayni hak edinmeleri serbesttir denilmiştir. Hukuk devletinin yukarda belirtilen işlevlerinin yaşama geçirilebilmesi bağlamında milli ekonominin ulusal çıkarlar doğrultusunda düzenlenebilmesi için yabancı yatırımcıların edineceği taşınmaz mülkiyeti ve sınırl ayni hakların iktisap amacl, kullanım şekli ve devrine ilişkin esas ve usullerin Yasada belirlenmesi gerekirken bu yönde hiçbir düzenleme yapılmamış olması belirsizliklere yol açmakta ve yabancı yatırımcılara sınırsız bir şekilde taşınmaz mülkiyeti ve sinırlı ayni hak edinme olanağı tanınmaktadır. Açıklanan nedenlerle kural, Anayasa'nın 2. maddesine aykırıdır; ..." d" bendinin Anayasa'ya aykırı olduğuna ve IPTALINE " hükmedilmiştir.

69 Konu ile ilgili geniş bilgi için bkz. Ekşi, Nuray: Yabancıların Türkiye'de Taşınmaz İktisab1, 2. Bas1, Beta, İstanbul, 2012.

70 RG: $29.12 .1934-2892$.

$71 \quad$ RG: $18.05 .2012-28296$.

722 Temmuz 2018 tarihli ve 698 sayılı KHK'nın 9 uncu maddesiyle, bu fikrada yer alan "Bakanlar Kurulu” ibareleri "Cumhurbaşkanı” şeklinde değiştirilmiştir; RG: 04.07.2018 -30468 . 
tarafindan belirlenen ülkelerin vatandaşı olan yabancı uyruklu gerçek kişiler Türkiye'de taşınmaz ve sinırlı ayni hak edinebilirler. Yabancı uyruklu gerçek kişilerin edindikleri taşınmazlar ile bağımsız ve sürekli nitelikteki sınırlı ayni hakların toplam alanı, özel mülkiyete konu ilçe yüz ölçümünün yüzde onunu ve kişi başına ülke genelinde otuz hektarl geçemez. Bakanlar Kurulu ${ }^{73}$ kişi başına ülke genelinde edinilebilecek miktarı iki katına kadar artırmaya yetkilidir.

Kanun hükmünden de görüldüğ̈ üzere, 6302 sayılı Kanun ile yapılan değişiklikle birlikte, Lozan Antlaşmasından Kanunun yürürlüğe girdiği tarihe kadar olan süreçte, yabancı gerçek kişilerin Türkiye'de taşınmaz edinimi bakımından, esas olan karşılıklılık esasından vazgeçilmiş ${ }^{74}$ ve konu ile ilgili Cumhurbaşkanına, ülke menfaatlerini dikkate alarak, taşınmaz edinme hakkı tanınacak ülke vatandaşlarını ${ }^{75}$ tespit etme ${ }^{76}$ yetkisi verilmiştir.

Yabancı gerçek kişilerin taşınmaz edinimi Kanun'un madde 35/1 hükmü ile kanuni sınırlamalara tabi tutulmuş ve fakat Cumhurbaşkanı kararı ile bu miktar, iki katına kadar arttırılabilmekle birlikte, hangi hallerde 30 hektarın 60 hektara çıkarılabileceği belirtilmemiştir ${ }^{77}$.

Doğan'a göre, yabancı gerçek kişilerin ülkede taşınmaz edinebilmesi bakımından Kanun ile esnek bir düzenleme getirilmiş, zira yabancıların ülke menfaatleri doğrultusunda Türkiye'de taşınmaz mal edinimi kısmen veya tamamen durdurulabilecek, sinırlanabilecek ya da yasaklanabilecektir. Bu şekilde esnek düzenlemenin kabul edilmesi ise, uluslararası alanda meydana gelebilecek değişikliklerin nazara alınabilmesine imkân sağlayabilecektir ${ }^{78}$.

Yabancı gerçek kişiler dışında, Tapu Kanunu ile yabancı tüzel kişilere de Türkiye'de taşınmaz edinme hakkı tanınmıştır (m.35/2). Hükme göre: 2) Yabancı ülkelerde kendi ülkelerinin kanunlarına göre kurulan tüzel kişiliğe sahip ticaret şirketleri ancak özel kanun hükümleri çerçevesinde taşınmaz ve sinırlı aynî hak edinebilirler. Bu ticaret şirketleri dişındakiler taşınmaz edinemez ve lehlerine sınırl ayni hak tesis edilemez. Bu ticaret

73 Bkz. dip.71.

74 Doğan, Vahit: Türk Yabancılar Hukuku, Güncellenmiş 3. Baskı, Savaş Yayınevi, Ankara, 2018, s. 261.

75 Türkiye'de hangi ülke vatandaşlarına taşınmaz edinme hakkının tanındığına ilişkin bilgi için bkz. Doğan, s. 263-264, dip. 236 ve 237.

76 Çelikel/Öztekin Gelgel'e göre, yeni düzenlemede örtülü karşılıklılıktan bahsetmek mümkündür; Çeliken/Öztekin Gelgel, s. 255.

77 Ekşi, s. 127.

78 Doğan, s. 264. 
şirketleri ile yabancı uyruklu gerçek kişiler lehine taşınmaz rehni tesisinde bu maddede yer alan sinırlamalar uygulanmaz...". Hükümden anlaşıldığg üzere, kanun koyucu, yalnızca yabancı ticaret şirketlerine özel kanunlar ${ }^{79}$ kapsamında Türkiye'de taşınmaz edinme ve sınırlı aynî hak tesis edilmesine hak tanımıştır. Bu da demek oluyor ki, tüzel kişiliğe sahip yabancı dernekler ile yabancı vakıfların Türkiye' de taşınmaz edinimi söz konusu değildir.

Bu bağlamda belirtilmeli ki, 2003 tarihli 4916 sayılı Kanun'un ${ }^{80}$ kabulünden önce, yabancı tüzel kişilerin Türkiye'de taşınmaz edinimine ilişkin herhangi bir düzenleme mevcut değildi.

Doğan'a göre, Tapu Kanunu madde 35/2 hükmünün uygulanması bak1mından üzerinde durulması gereken bir husus var; acaba yabancı ticaret şirketleri yatırım amacı dişında Türkiye'de taşınmaz mal edinebilirler mi? Yazara göre, yabancı ticaret şirketlerine bu hakkın tanınmasının temel gerekçesi, yabancı sermayeyi ülkeye çekmek ve yabancı sermayeye gerekli kolaylıkları sağlamaktır. Bizim de katıldığımız bu görüşe göre, yabancı ticaret şirketlerine taşınmaz mal edinme hakkının tanınmasının, yatırım amacına yönelik olması gerektiği yönündedir ${ }^{81}$.

Kanun'un 36/1.maddesinde ise, yabanc1 sermayeli şirketlerin Türkiye'de taşınmaz edinimi düzenlenmiştir. Madde hükmüne göre: "29.05.2009 tarihli ve 5901 sayll Türk Vatandaşlı̆̆l Kanununun 28 inci maddesi kapsamındaki kişiler hariç olmak üzere, yabancı uyruklu gerçek kişilerin, yabancı ülkelerin kanunlarına göre kurulmuş tüzel kişilerin ve uluslararası kuruluşların yüzde elli veya daha fazla oranda hissesine sahip oldukları veya yönetim hakkını haiz kişilerin çoğunluğunu atayabilme veya görevden alabilme yetkisine sahip oldukları Türkiye'de kurulu tüzel kişiliğe sahip şirketler, ana sözleşmelerinde belirtilen faaliyet konuların yürütmek üzere taşınmaz mülkiyeti veya sinırlı ayni hak edinebilir ve kullanabilirler...".

Birinci fikrada belirtilen şirketlerin Türkiye'de kurulu başka bir şirkete doğrudan veya dolaylı olarak ortak olması durumunda, yabancı yatırımcının ortak olunan şirketteki nihai ortaklık oranının yüzde elli veya daha fazla olması halinde; yabancı yatırımcıların, taşınmaz maliki yerli sermayeli şirketlerin hisselerinin yüzde elli veya daha fazlasını doğrudan veya dolayl

79 Bu kanunlardan bazıları, 6491 say1l ve 2013 tarihli Türk Petrol Kanunu (RG: 11.06.2013-28674); 4737 sayılı ve 2002 tarihli Endüstri Bölgeleri Kanunu (09.01.200224645); 2634 sayılı ve 1982 tarihli Turizmi Teşvik Kanunu (16.03.1982-17635) vb.

80 RG: 19.07.2003-25173.

81 Doğan, s. 293. 
olarak edinmesi ve taşınmaz maliki mevcut yabanci sermayeli şirketlerde yabanct yatırımcıların ortaklık oranının hisse devri sonucunda yüzde elli veya daha fazlasına ulaşması durumunda da aynı esaslar geçerlidir (m.36/2).

Yukarıda belirtilmiş hükümlere göre, yabancı sermaye mevzuatı kapsamında Türkiye'de kurulacak veya iştirak edilecek Türk tabiiyetindeki ticaret şirketleri, ana sözleşmelerinde belirtilmiş olan faaliyet konuları ile sınırlı olmak üzere, Türkiye'de taşınmaz mallar üzerinde mülkiyet ve sınırlı aynî hak edinebileceklerdir.

Bununla birlikte, 4875 sayıl Kanun ile "yabancı yatırımcı" kapsamına alınan yurt dışında ikamet eden Türk vatandaşları ile yetkili makamlardan izin alarak Türk vatandaşlığından çıkan kişiler için (Mavi Kartlılar) Tapu Kanunu'nda öngörülen sinırlamalar uygulanmayacaktır. Zira bahsi geçen kişilerin, kurdukları veya Kanunda tespit edilen oranda iştirak etmiş oldukları şirketler, taşınmaz mal edinirken, öngörülen sınırlamalara tabi tutulmayacaklardir $^{82}$.

Nitekim Tapu Kanunu'nun 36. maddesinin 1 ve 2. fikraları kapsamı dışında kalan yabancı sermayeli şirketlerin taşınmaz edinmesi ile ilgili bahsi geçen Kanun'da şu hükme yer verilmiştir: "yerli sermayeli şirketlerin tabi olduğu hükümler çerçevesinde taşınmaz mülkiyeti ve sınırlı aynî hak edinebilir ve kullanabilirler (m.36/4). Hükümden de anlaşıldığı üzere, yabanc1ların sahip oldukları hisse miktarının yüzde ellinin altında olduğu Türkiye'de kurulu ve tüzel kişiliğe sahip şirketler, yerli veya başka bir ifadeyle, Türk sermayeli şirketler gibi taşınmaz mal ve sınırlı aynî hak edinebilecektir.

Ayrıca belirtmek gerekir ki, Tapu Kanunu'nun 36.maddesinin 8.fikrasina istinaden 2012 yılında Tapu Kanunu'nun 36.maddesi Kapsamındaki Şirketlerin ve İştiraklerin Taşınmaz Mülkiyeti ve Sınırlı Aynî Hak Edinimine İlişkin Yönetmelik ${ }^{83}$ çıkarılmıştır. Yönetmeliğin amacı ise madde $1 / 1$ 'de şu şekilde ifade edilmiştir: "Bu Yönetmeliğin amacı, 2644 sayılı Tapu Kanununun 36. maddesi kapsaminda yer alan şirketlerin ve bu şirketlerin Türkiye'deki iştiraklerinin, Türkiye'de taşınmaz mülkiyeti ve sınırlı aynî hak edinimine ve kullanımına ilişskin usûl ve esasları düzenlemektir".

Son olarak belirtmek gerekir ki, yabancıların Türkiye'de taşınmaz edinimine ilişkin bazı yasal düzenlemeler ile sınırlama getirilmiştir. Bunlardan en önemlileri ise 1981 tarihli ve 2565 sayılı Askeri Yasak Bölgeler ve

82 Doğan, s. 311-312.

83 RG: $16.08 .2012-28386$. 
Güvenlik Bölgeleri Kanunu ${ }^{84}$ ile 1927 tarihli ve 1062 sayılı Mukabele-i Bilmisil Kanunu'dur ${ }^{85}$.

\section{ff. Yatırım Uyuşmazlıklarının Çözümü}

Yatırım uyuşmazlıklarının çözümü ${ }^{86}$ ile ilgili hüküm 4875 sayılı DYYK'nın madde 3/(e)'de yer almıştır. Hükme göre; “Özel hukuka tabi olan yatırım sözleşmelerinden kaynaklanan uyuşmazlıkların çözümü ile yabancı yatırımcıların idare ile yaptıkları kamu hizmeti imtiyaz şartlaşma ve sözleşmelerinden doğan yatırım uyuşmazlıkların çözümlenmesi için, görevli ve yetkili mahkemelerin yanında, ilgili mevzuatta yer alan koşulların oluşması ve tarafların anlaşması kaydıyla, milli veya milletlerarası tahkim veya diğer uyuşmazlık çözüm yollarına başvurulabilir.

Hükümden de anlaşıldığı üzere, yatırım uyuşmazlıklarının çözümü bakımından ulusal mahkemelerin yanında milli ve milletlerarası tahkime ${ }^{87}$ de başvurulabileceği öngörülmüştür ve tarafların bu konuda anlaşması yeterlidir.

Yarg1, kural olarak, devlete ait bir fonksiyondur. Yarg1 fonksiyonunu üstlenen devlet, bu görevini kurduğu mahkemeler aracıllğı ile yerine getirmektedir. Ancak özel hukuka ilişkin uyuşmazlıkların çözümünde bazı hallerde, bu uyuşmazlığın mahkemeler yerine tahkim yolu ile hakemler tarafindan çözümüne izin verilmektedir ${ }^{88}$.

Uyuşmazlıkların tahkim yolu ile çözülmesi, tarafların bu yolu tercih etmiş olmaları şartına bağlıdır. Bu sebeple, tarafların bu husustaki iradelerini

$84 \quad$ RG: $22.12 .1981-17552$.

85 RG: 15.06.1927-608.

86 "Doğrudan yabancı yatırımlardan doğan uyuşmazlıkların çözümünde yargı yetkisi ve uygulanacak hukuk konusunda Türk hukuk sisteminde bazı engeller ve adaletin sağlanmasındaki gecikmeler, yabancl yatırımclların Türkiye'ye yatırım yapmakta isteksiz olmalarının önemli nedenlerinden biri olarak gösterilmektedir. Hukuk ve yargı sisteminin hakkın elde edilmesinde tereddüt doğurmaması için reform çalışmaları kapsamında, yeni yasal düzenlemelerin kabulü yoluna gidilmiştir"; Çelikel, s. 170.

87 Ataman Figanmeşe'ye göre, her ne kadar doktrinde yazarların çoğu, yatırım uyuşmazlıklarının çözümü bakımından ICSID Tahkim Merkezi’ni adres olarak gösterseler de, bununla birlikte, günümüzde yatırım uyuşmazlıklarının kayda değer bir kısmının da milletlerarası ticari tahkimlerde (ad hoc ve daimi tahkim merkezleri) görüldüğü bir gerçektir; Ataman Figanmeşe, İnci: "Milletlerarası Ticari Tahkim ve Yatırım Tahkimi Arasındaki Farklar", Public and Private International Law Bulletin, Volume: 31, Issue: 1, s. 97.

88 Pekcanıtez, Hakan/Atalay, Oğuz/Özekes, Muhammet: Medeni Usul Hukuku, Ders Kitabı, 5. Bası, Vedat Kitapçılık, İstanbul, 2017, s. 579. 
açıklamış olmaları tahkim şartı veya sözleşmesi yapmış olmalarına bağlıdır. Tahkim şartının geçerli olabilmesi için tarafların, uyuşmazlığın tahkim yolu ile çözülmesi gerektiği yolundaki iradelerini tahkim şartında açık bir şekilde ifade etmiş olmaları gerekir. Bu sebeple uyuşmazlığın tahkim yolu ile mi yoksa devlet yargısında mı çözüleceği hususunda tereddüt uyandıran, ya da her ikisini birden yetkili kılan tahkim şartı veya sözleşmeleri, bu husustaki taraf iradesi açık ve kesin olmadığı için geçersiz sayılacaktır ${ }^{89}$.

Türk hukukunda yabancı unsurlu uyuşmazlıkların tahkim yoluyla çözümü detaylı bir şekilde 2001 tarihli 4686 sayılı "Milletlerarası Tahkim Kanunu'nda (MTK) ${ }^{90}$ düzenlenmiştir. Konumuz açısından söz konusu Kanunun ilgili hükümlerine değinmekte yarar vardır.

Kanunun 1'inci maddesine göre: "Bu Kanun, yabancllk unsuru taşlyan ve tahkim yerinin Türkiye olarak belirlendiği veya bu kanun hükümlerinin taraflar ya da hakem veya hakem kurulunca seçildiği uyuşmazlıklar hakkinda uygulanir".

Bununla birlikte 4686 sayılı Kanun, Türkiye'de bulunan taşınmaz mallar üzerindeki ayni haklara ilişkin uyuşmazlıklar ile iki tarafın iradelerine tabi olmayan uyuşmazlıkların söz konusu olduğu hallerde uygulanmaya$\operatorname{caktır}(\mathrm{m} .1 / 3)$.

Anayasanın 125.maddesinde yapılan değişiklikten sonra, 2000 tarihli ve 4501 sayılı Kamu Hizmetleri ile İlgili İmtiyaz Şartlaşma ve Sözleşmelerinden Doğan Uyuşmazlıklarda Tahkim Yoluna Başvurulması Halinde Uyulması Gereken İlkelere Dair Kanun ${ }^{91}$ kabul edilmiştir. Kanun ile yabancılık unsuru taşıyan imtiyaz sözleşmelerinden doğan uyuşmazlıkların tahkim yolu ile çözümlenebileceği hüküm altına alınmıştır (m.3).

Ancak 4501 sayılı Kanun kapsamındaki tahkimlerin de daha sonra çıkarılan 4686 sayılı MTK'ya göre yürütüleceği kabul edilmiştir. 4686 sayılı Kanun uyarınca, yabancılık unsurunun bulunduğu kamu hizmetleri ile ilgili imtiyaz şartlaşma ve sözleşmelerinden doğan uyuşmazlıkların milletlerarası tahkim yoluyla çözülmesi de bu Kanuna tabi kılınmıştır (4686 sayılı MTK m.1/4).

89 Pekcanıtez/Atalay/Özekes, s. 579; Akıncı, Ziya: Milletlerarası Özel Hukukta İnşaat Sözleşmeleri (İnşaat Sözleşmeleri), DEÜ Döner Sermaye İşletmesi Yayınları, No: 73, İzmir, 1996, s. 155-156; Yılmaz, İlhan: Uluslararası Yatırım Uyuşmazlıklarının Tahkim Yoluyla Çözümü ve ICSID, Beta, İstanbul, 2004, s. 56-57; Akıncı, Ziya: Milletlerarası Tahkim (Tahkim), 3. Bası, Vedat Kitapçılık, İstanbul, 2013, s. 95 vd.

90 RG: 05.07.2001-24453. Bundan sonra kisaca 4686 sayılı MTK olarak anılacaktır.

$91 \quad$ RG: $22.01 .2000-23941$. 
4686 sayılı Kanun'un 2. maddesinde yabancılık unsurunu taşıyan haller ${ }^{92}$ belirtilmiş ve bu hallerden herhangi birinin mevcudiyeti söz konusu olduğunda tahkimin milletlerarası niteliğini kazanacağı vurgulanmıştır. Konumuz açısından bahsi geçen maddenin 3. fikrası önem taşımaktadır. Hükme göre: "Tahkim anlaşmasının dayanağını oluşturan asıl sözleşmeye taraf olan şirket ortaklarından en az birinin yabancı sermayeyi teşvik mevzuatına $^{93}$ göre yabancı sermaye getirmiş olmast veya bu sözleşmenin uygulanabilmesi için yurt dlşından sermaye sağlanması amacıyla kredi ve/veya güvence sözleşmeleri yapılmasının gerekli olması" halinde uyuşmazlık, 4686 sayılı MTK kapsamında olacaktır (m. 2/3).

Dolayısıyla, yabancı yatırımdan kaynaklanan uyuşmazlıkların çözümlenmesi bakımından taraflar, şartları sağlamak kaydıyla, görevli ve yetkili mahkemelerin yanı sıra milletlerarası tahkime de gidebilmektedir.

Ayrıca, yatırım uyuşmazlıkları ile ilgili olarak, Türkiye ${ }^{94}$ ve Kazakistan'1n ${ }^{95}$ taraf olduğu 1965 tarihli Devletler ve Diğer Devletlerin Vatandaşları Arasındaki Yatırım Uyuşmazlıklarının Çözümlenmesi Hakkında Sözleşme (International Center for the Settlement of Investment Disputes-ICSID) ${ }^{96}$ ile Sözleşme kapsamındaki yatırım uyuşmazlıklarının çözümü için merkezi Washington'da bulunan uluslararası bir Merkez kurulmuştur. İleride ICSID tahkimi ile ilgili bilgi verileceğinden burada üzerinde durulmayacaktır.

92 Söz konusu haller ise şunlardır: "1. Tahkim anlaşmasının taraflarının yerleşim yeri veya olağan oturma yerinin ya da işyerlerinin ayrı devletlerde bulunması. 2. Tarafların yerleşim yeri veya olağan oturma yerinin ya da işyerlerinin: a) Tahkim anlaşmasında belirtilen veya bu anlaşmaya dayanarak tespit edilen hallerde tahkim yerinden, b) Asıl sözleşmeden doğan yükümlülüklerin önemli bir bölümünün ifa edileceği yerden veya uyuşmazlık konusunun en çok bağlantılı olduğu yerden başka bir devlette bulunması. 3 . Tahkim anlaşmasının dayanağını oluşturan asıl sözleşme veya hukuki ilişkinin, bir ülkeden diğerine sermaye veya mal geçişini gerçekleştirmesi”. (4686 sayılı Kanun, m. 2).

93 Mevzuatta, 6224 sayıla mülga YSTK'ya yapılan atıflar, DYYK'nın ilgili hükümlerine yapılmış sayılır (4875 sayılı DYYK, m.5/c).

94 RG: 6.12.1988-20011.

95 Zakon Respubliki Kazakhstan ot 26.07.1992 “O Çlenstve Respubliki Kazakhstan v Mnogostoronnem Agentstve po Garantiyam İnvestitsiy (MIGA) i Mejdunarodnom Tsentre po Uregulirovaniyu İnvestitsionnı Sporov (ICSID), Ведомости Верховного Совета Республики Казахстан, (Vedomosti Verhovnogo Soveta Respubliki Kazahstan) 1992, No:13-14, ст. 311.

96 Sözleşme metni için bkz: (RG: 6.12.1988-20011); Bundan sonra kısaca ICSID Sözleşmesi olarak anılacaktır. 


\section{gg. Nakit Dışı Sermayenin Değer Tespiti}

Nakit dışındaki sermayenin değer tespiti, Türk Ticaret Kanunu hükümleri çerçevesinde yapılır (4875 sayılı DYYK, m.3/f). Buna göre: "Yabancı ülkelerde kurulu bulunan şirketlerin menkul kıymetlerinin yatırım aracı olarak kullanılması halinde, menşe ülke mevzuatına göre değer tespitine yetkili makamların veya menşe ülke mahkemelerince tespit edilecek bilirkişilerin ya da uluslararası değerlendirme kuruluşların değerlendirmeleri esas alınır".

$\mathrm{Bu}$ hükümle 6224 sayılı YSTK'nın yürürlükte olduğu dönemde var olan önemli sıkıntılardan bir tanesi aşılmış bulunmaktadır, zira eski mevzuat döneminde nakit dışı sermayenin değer tespiti, Hazine ve Dış Ticaret Müsteşarlığı bünyesinde görevli eksperler tarafından yapılmaktaydı (YSTK, m.2/b). Bu uygulama uzun ve zahmetli bir takım bürokratik engellerin aşılmasını gerektirmekteydi ve doğal olarak, yabancı yatırımcılar açısından cazip bir durum değildi ${ }^{97}$.

Böylece, 4875 sayı1ı DYYK'nın madde 3/f hükmü ile nakit dışı sermayenin değer tespitine ilişkin yeniliğin getirilmesi, yabancı yatırımcı bakımından olumlu bir değişiklik olarak nitelendirilebilmektedir.

\section{hh. Yabancı Personel İstihdamı}

6735 sayılı ve 2016 tarihli Uluslararası İşgücü Kanunu'nun ${ }^{98}$ madde 25/2(b)'de, “4875 sayıl DYYK kapsamındaki yabancı sermayeli şirket ve kuruluşlarda çalışma izni verilecek personelin tanımı ile çalışma izinlerine ilişkin özel nitelikteki diğer usul ve esaslar", Ekonomi Bakanlığ ${ }^{99}$ ve Çalışma ve Sosyal Güvenlik Bakanlıkça ${ }^{100}$ müştereken çıkarılacak olan yönetmelikle düzenleneceği hüküm altına alınmış ve henüz bahsi geçen yönetmelik çıkarılmamıştır ${ }^{101}$.

\section{Demir Gökyayla/Süral, s. 150.}

98 RG: 13.08.2016-29800. Bundan sonra kısaca 6735 sayılı UiK olarak anılacaktır.

99 Bakanlığın adı, Gümrük ve Ticaret Bakanlığı ile birleştirildikten sonra, Ticaret Bakanlığı olarak değiştirilmiştir; bkz. Anayasada Yapılan Değişikliklere Uyum Sağlanması Amacıyla Bazı Kanun ve Kanun Hükmünde Kararnamelerde Değişiklik Yapılması Hakkında 703 sayılı KHK; RG: 09.07.2018-30473.

100 Bakanlığın adı Aile, Çalışma ve Sosyal Hizmetler Bakanlığı olarak değiştirilmiştir; "Bazı Cumhurbaşkanlığı Kararnamelerinde Değişiklik Yapılması Hakkında Cumhurbaşkanlığ1 Kararnamesi; Kararname Numaras1, 15, madde 1(a), RG: 04.08.2018-30499. 6735 sayılı UİK'in madde 25/2(a) hükmü doğrultusunda Çalışma ve Sosyal Güvenlik Bakanlı̆̆ 1 ve Ekonomi Bakanlığınca "Serbest Bölgelerde Çalışacak Yabancıların Çalışma İzinlerine Dair Yönetmelik" 27 Mayıs 2017 tarihinde Resmi gazetede yayınlanmıştır; RG: 27.05.2017-30078.

1016735 sayılı UİK çıkmadan önce, özellik arz eden doğrudan yabancı yatırımlarda ve irtibat bürolarında istihdam edilecek yabanc1 uyruklu kilit personel ile ilgili usul ve 
Kanaatimizce, 4875 sayılı Kanun kapsamında istihdam edilecek personele çalışma izninin verilmesi, diğer yabancılara nazaran, kolaylaştırılmış usule tabi tutulmalı, zira bu yönde hazırlanmış olan bir düzenlemenin yabancı yatırımların teşviki bakımından etkili olabileceği görüşündeyiz.

\section{Kazak Hukukunda}

Kazak hukukunda, Türk hukukunda olduğu gibi, yatırımlara ilişkin mevzuatın temel kaynağını Kazakistan Cumhuriyeti'nin 1995 tarihli Anayasası $^{102}$ teşkil etmektedir. Yatırımlara ${ }^{103}$ ilişkin düzenlemeler ise esasen 375-V sayılı ve 29 Ekim 2015 tarihli Kazakistan Cumhuriyeti Girişimcilik Kanunu"nda ${ }^{104}$ yer almaktadır.

Aşağıda Kazakistan Cumhuriyeti Anayasası ile Girişimcilik Kanununda yer alan esaslara değinilecektir.

\section{a. Anayasa}

Yabancı yatırımları düzenleyen 2015 tarihli Girişimcilik Kanunu'nun madde 1'de, “Kazakistan Cumhuriyeti'nde girişimcilik faaliyetine ilişkin mevzuatın yasal dayanağının Anayasa" olduğu ifade edilmektedir.

Öncelikle belirtmek gerekir ki, Kazakistan Anayasas1 madde 4/3 ile milletlerarası sözleşmelere ülke kanunları karşısında üstünlük sağlamaktadır.

esaslar, 2003 tarihli Doğrudan Yabancı Yatırımlarda Yabancı Uyruklu Personel İstihdamı Hakkında Yönetmelik (DYYYUPIHY) (RG: 29.08.2003-25214) hükümlerine tabi tutulmuş idi (m.2). Ayrıca, özellik arz eden doğrudan yabancı yatırımlarda istihdam edilecek kilit personel dışında kalan yabancı uyruklu personel ile özellik arz eden doğrudan yabancı yatırımların dışında kalan doğrudan yabancı yatırımlarda istihdam edilecek yabancı uyruklu her türlü personelin çalışma izinlerinde 4817 sayılı Yabancıların Çalışma İzinleri Hakkında Kanun (RG: 06.03.2003-25040) ve Yabancıların Çalışma İzinleri Hakkında Kanunun Uygulama Yönetmeliği (RG: 29.008.2003-25214) hükümleri uygulanmakta idi (DYYYUPİHY m.2 (a.b)).

102 “Казахстанская Правда (Kazahstanskaya Pravda), 30.08.1995. Son değişiklikler 2011 yılında yapılmıştır. Kazahstanskaya Pravda, Vedomosti Parlamenta ve Vedomosti Verhovnogo Soveta Respubliki Kazahstan, Kazakistan Cumhuriyeti'nin kanun, Bakanlar Kurulu kararları ve yönetmelikler gibi, hukuk kaynaklarının yayınlandığı resmi gazete ve bültenlerdir.

103 Kazakistan Cumhuriyeti'nde 2003 tarihinden itibaren yerli-yabancı yatırım ayrımı yapılmamaktadır. 2015 tarihli ve 375-V sayılı Girişimcilik Kanunu (madde 274), mülga 373II sayılı ve 2003 tarihli "Yatırımlar Kanunu" (m. 1/3).

104 Orijinal isim: "Предпринимательский Кодекс Республики Казахстан”, Казахстанская Правда (Kazahstanskaya Pravda) от 03.11.2015 года,No:210(028086), Ведомости Парламента (Vedomosti Parlamenta) PК 2015, No:20-III, ст.112; Bundan sonra kısaca Girişimcilik Kanunu olarak anılacaktır. 
Ayrıca, Kazak hukuk sisteminde de yabancılar bakımından, kural olarak, eşitlik sistemi kabul edilmiştir. Anayasa madde 14'e göre, "Herkes kanun ve mahkeme karşısında eşittir. Hiç kimse menşe, sosyal, mesleki ve mülk durumu, cinsiyet, ırk, milliyet, din, dil, görüşü, ikamet yeri ve başka gerekçelerle farkl muameleye tabi tutulamaz". Benzer hüküm Anayasa madde 12/4'te de yer almaktadır. Hükme göre, "Yabancılar ve vatandaşlı̆gl olmayan kimseler (vatansizlar), Kazakistan Cumhuriyeti'nde bulundukları süre içinde, kanunla veya uluslararası sözleşmeler ile aksi belirtilmediği sürece, Kazakistan Cumhuriyeti vatandaşları ile aynı hak ve yükümlülüklere sahiptir". Hükme göre, Kazakistan Cumhuriyeti topraklarında sürekli veya geçici olarak kalan yabancılar ve vatansızların hak ve yükümlülükleri, Türk hukukunda olduğu gibi, uluslararası hukuk kuralları ve Kazakistan Cumhuriyeti kanunlarına uygun bir şekilde bazı durumlarda sınırlandırılabilir.

Kazakistan Cumhuriyeti Anayasası genel olarak temel haklardan herkesin, vatandaş-yabancı ayrımı gözetmeksizin yararlanması esasını kabul etmiş ve yabancıların yararlanamayacağı hakları düzenlerken, Türk hukukunda olduğu gibi, yalnız "Kazakistan Cumhuriyeti vatandaşları" terimini kullanmıştır (siyasi haklar gibi) (Anayasa, m. 33).

Anayasada çeşitli hak ve özgürlükler düzenlenirken, hakkın özüne dokunulmadan bazı sınırlamaların yapılabileceği de kabul edilmiştir. Kamu düzeni ve kamu güvenliği, kamu ahlâkı gibi nedenlerle vatandaşlar açısından getirilen sınırlamalar, şüphesiz yabancılar için de söz konusu olacaktır (Anayasa, m.39).

Ayrıca, yabancı yatırımcılar açısından Kazakistan Cumhuriyeti Anayasası'nın madde 26/4'ü önem taşımaktadır. Bu madde hükmüne göre: "Herkes dilediği alanda çalışma hürriyetine sahiptir. Özel teşebbüs kurmak serbesttir. Tekel niteliğinde faaliyetler kanunla düzenlenmekte ve sinirlandirllmaktadır. Haksız rekabet yasaklanmaktadır".

Hükümden de anlaşıldığı üzere, Kazakistan'da yabancı yatırımcıların yatırım faaliyetinde bulunması bakımından anayasal bir engel bulunmamakta ${ }^{105}$, zira herkes kavramı ile Anayasada vatandaş-yabancı ayrımı gözetilmemiştir.

Bununla birlikte, yukarıda da bahsedildiği üzere, Kazakistan'da yat1rımlar 2015 tarihli Girişimcilik Kanunu ile düzenlenmektedir. Ancak ülkenin

105 Maulenov, K. S.: Государственное Управление и Правовое Регулирование в Сфере Иностранных Инвестиций в Республике Казахстан (Gosudarstvennoye Upravleniye i Pravovoye Regulirovaniye v Sfere İnostrannıh İnvestitsiy v Respublike Kazakhstan), Almat1, 2000, s. 78. 
yabancı yatırım mevzuatının başlangıcı 1990 yılına uzandığından, aşağıda yatırım mevzuatının tarihçesine kısaca değinilecek ve akabinde Girişimcilik Kanunu'nda yer alan esaslara yer verilecektir.

\section{b. Kazakistan'da Yatırım Mevzuatının Tarihçesi}

Kazakistan Cumhuriyeti'nde yabancı yatırımları düzenleyen mevzuatın günümüze kadar beş önemli dönemden geçtiğini söylemek mümkündür ${ }^{106}$. Şöyle ki:

Birinci dönem: $\mathrm{Bu}$ dönemde Kazakistan yatırım mevzuatının temelini oluşturan 383-XII sayılı ve 7 Aralık 1990 tarihli Kazak Sovyet Sosyalist Cumhuriyeti'nin "Yabancı Yatırımlar Hakkında Kanun"u ${ }^{107}$ kabul edilmiştir.

Kanunun amacı, yabancı sermayeye gerekli garantileri sağlayarak, yabancı yatırımların ülkeye akışını teşvik etmek olmuştur. Ayrıca bu Kanun ile Kazakistan ekonomisinin dişa açılması ile birlikte, küresel ekonomiye de entegrasyonunu sağlayacak koşulların oluşturulması hedeflenmişti.

Eksiklikleri olmasına rağmen, bu Kanun ile yabancı yatırımcılara ülkede 11 ımlı yatırım ortamının sağlanacağına yönelik sinyaller de verilmişti ${ }^{108}$.

İkinci dönem: 1990 tarihli Kanun tam dört y1l kadar kısa bir süre yürürlükte kaldıktan sonra, 27 Aralık 1994 yılında kabul edilen 266-XIII sayılı Kazakistan Cumhuriyeti "Yabancı Yatırımlar Kanunu" ${ }^{109}$ ile yürürlükten kaldırılmıştır.

$\mathrm{Bu}$ Kanunun en önemli özelliği ise, Kazakistan'a doğrudan yabanc1 yatırımları teşvik edecek çerçeveyi belirlemesi olmuştur. Ayrıca, Kanun ile

106 Suleymenov, M. К.: “Законодательство об инвестициях Республики Казахстан: 25 лет развития", (Kazakistan Cumhuriyeti Yatırımlar Mevzuatı 25.yılında, "Yer altı kaynakları-Kazakistan Cumhuriyeti Ekonomisinin Temeli" başlıklı 28.04.2017 tarihli konferansında tebliği.

107 Ведомости Верховного Совета Казахской ССР, 1990 г., o: 50, ст. 473 (Vedomosti Verhovnogo Soveta Respubliki Kazakhstan, 1990, No:50, st. 473).

108 Suleymenov, s. 2.

109 Ведомости Верховного Совета Республики Казахстан (Vedomosti Verhovnogo Soveta Respubliki Kazakhstan), 1994 г., N 23-24, ст. 280. Doğal zenginlikleriyle tüm dünyada ün salan Kazakistan'da, Sovyetler Birliği'nin 27 Aralık 1991 yılında dağılması ile birlikte, kısa süreli bir şok yaşanmış ve ülke ekonomisinin kalkındırılması için acilen yabancı yatırımlara ihtiyaç duyulmakta idi. Fakat öncelikle, şartlara uygun olarak yabancı yatırımlar ile ilgili yasal düzenlemenin hazırlanması gerekiyordu. Kazakistan Cumhuriyeti'nin ilk 1990 tarihli Yabancı Yatırımlar Hakkında Kanunu ise Sovyetler Birliği'nin dağılmasından bir sene önce çıkarılmıştı ve yeni gelişmelere uyum sağlayamiyordu. 
doğrudan yabancı yatırımların teşviki amacıyla çeşitli garantilerin sağlandığını da söylemek mümkün olacaktır.

Nitekim 1994 tarihli Kanun, öncelikle, yabancı yatırımcıların menfaatleri ile yabancı yatırımlar için en çok elverişli rejimin oluşturulmasını amaçlamaktaydı. Bu durum da yerli yatırımc1 yanı sıra, devletin de menfaatlerini zedelemekte idi. Şöyle ki, "ne pahayla olursa olsun yabancı sermaye yatırımları ülkeye çekilmeli" prensibine uyularak, yabancı yatırımcılara birçok avantaj sağlanmaktayd $1^{110}$.

Üçüncü Dönem: 1994 tarihli Yabancı Yatırımlar Kanunu'nu geliştirme ve etkinleştirme amaciyla 28 Şubat 1997 yılında kabul edilen Kazakistan Cumhuriyetinin Yabancı Yatırımlara Devlet Desteği Hakkında Kanunun ${ }^{111}$ önemi büyük olmuştur. Bu Kanunun başlıca amaçlarını şu şekilde belirtmek mümkün olmaktadır: yeni teknoloji uygulamalarını teşvik etmek, teknik bilgi ve know-how alışverişi ile iç pazarda yüksek kaliteli tüketim malları ve hizmetlerin yerli üretimini özendirmek, ihracatı güçlendirmek, yeni iş yerleri oluşturmak, çevre şartlarını iyileştirmek vb.

Dördüncü dönem: 373-II sayılı ve 8 Ocak 2003 tarihli Yatırımlar Kanunu'nun ${ }^{112}$ kabulü ile 1994 tarihli ile 1997 tarihli her iki Kanun da yürürlükten kaldırılmıştır. Dikkat edilirse, yeni 2003 tarihli Kanun'un isminde "yabancı" kavramı yer almamaktadır. Bunun nedeni ise, yeni Kanun ile artık yerli-yabancı yatırım ayrımı yapılmaksızın, her iki yatırımın da aynı hukuki rejime tabi kılınması olmuştur.

Yeni Yatırımlar Kanunu'nu kısaca özetleyecek olursak Kanun, yabanc1 yatırımcılara ulusal yaklaşım ve fark gözetilmemesi konularında garanti sağlamakta ve Hükümet tarafından belirlenen öncelikli sektörlerde yatırım teşvikleri, gümrük vergi muafiyetleri ile yatırım vergi ayrıcalıkları içermekte ve bazı sektörlerdeki sınırlamalar haricinde, tüm diğer alanlarda yatırım yapılmasına izin vermekteydi ${ }^{113}$.

Doktrinde savunulan bir görüşe göre, 2003 tarihli Yatırımlar Kanunu, yerli yatırımcının hukuki statüsünü yabancı yatırımcının eski yatırım mev-

110 Kazakistan Mevzuatı, TİKA, Ankara, 1996.

111 Ведомости Парламента Республики Казахстан (Vedomosti Parlamenta respubliki Kazahstan) 1997 г., № 4, ст. 50.

112 “Казахстанская Правда (Kazakhstanskaya Pravda) No: 9-11(23948-23950)11.01.2003.

113 Kazakistan Ülke Profili, Avrasya Dosyası, Ankara, 2004; s. 4; http://www.katiad.kz; 17.02.2017. 
zuatında öngörülen statüsüyle eşleştirmek yerine, yabancı yatırımcının hukuki statüsünü yerli yatırımcının hukuki statüsüyle eşleştirmektedir. Ancak böyle bir yaklaşımın ne yabancı ne de yerli yatırımcı için avantaj sağlamadığı aşikârdır, zira yabancı yatırımcının hukuki statüsünün kötüleştiği yanı sıra, yerli yatırımcının hukuki statüsünde ise herhangi bir olumlu değişiklik yapılmamıştı1 ${ }^{114}$.

Beşinci dönem: Son dönemin başlangıcını ise, 2015 tarihli Girişimcilik Kanunu'nun kabul edilmesi teşkil etmektedir. Bu Kanunun 1 Ocak 2016'da yürürlüğe girmesi ile 2003 tarihli Yatırımlar Kanunu yürürlükten kaldırılmıştır.

Öncelikle belirtmek gerekir ki, yeni Girişimcilik Kanunu'nda da yerliyabancı yatırımcı ayrımı yapılmaksızın, ülkedeki tüm girişimcilik faaliyetleri ${ }^{115}$ düzenlenmektedir.

Nitekim Girişimcilik Kanunu'nun yatırımları düzenleyen 25. Bölümünde mülga 2003 tarihli Kanunda yer alan esaslara aynen yer verilmiş ve 273 ile 296. maddeleri arasında yatırımların hukuki rejimi düzenlenmiştir.

\section{c. 2015 tarihli Girişimcilik Kanunu}

Aslında kısa bir süre geçmesine rağmen (13 yıl), Kazak kanun koyucu, yatırımları düzenleyen yeni Kanuna ihtiyaç duymuş ve 2015 yılında Girişimcilik Kanunu'nu kabul etmiştir.

Yatırımların teşvikine yönelik esaslara değinmeden önce, aşağıda Kanunda yer alan yatırım ve yatırımcı kavramlarına kısaca göz atmanın faydalı olacă̆ kanısındayız.

\section{aa. Yatırım Kavramı}

Girişimcilik Kanunu madde 274/1'e göre yatırım, mülga 2003 tarihli Kanunda olduğu gibi: Yatırımcının (yerli-yabancl), sermaye olarak getirdiği tüm mülkiyet türleri (şahsi tüketim malları hariç) ile leasing anlaşması yapıldı $\breve{g}$ andan itibaren leasing araçları ve yetki haklarının yatırım olarak tüzel kişinin esas sermayesine yatırılan veya işletme faaliyeti için kullanılan kaydedilmiş aktiflerin arttırılması ",116 olarak tanımlanmıştır.

\footnotetext{
114 Suleymenov, s. 5; Moroz, S. Р.: Инвестиционное Право (İnvestitsionnoe Pravo), Almat1, 2003 s. 46-47.

115 Kanaatimizce, kanun koyucu, ülkedeki tüm girişimcilik faaliyetlerini, yatırım faaliyetleri de dâhil olmak üzere, tek bir Yasanın çatısı altında toplamayı amaçlamıştır.

116 Mülga Yatırımlar Kanunu madde 1/1.
} 
Tanımdan da anlaşıldığı üzere kanun koyucu, yatırım kapsamına sınai ve fikri mülkiyet haklarını dâhil etmemiştir. Konu ile ilgili Moroz'un görüşünün isabetli olduğu kanaatindeyiz, zira sınai ve fikri mülkiyet haklarının da yatırım kapsamına alınması, yabancı yatırımların teşviki bakımından yerinde bir düzenleme olabilirdi ${ }^{117}$. Buna karşın, sınai ve fikri mülkiyet haklarının Türk hukukunda yabancı yatırım kapsamında değerlendirildiğini görmekteyiz (DYYK, m. 2/1).

\section{bb. Yatırımcı Kavramı}

Mülga 2003 tarihli Kanunda olduğu gibi kanun koyucu, Girişimcilik Kanunu ile de yatırımcı kavramını ayrıma tabi tutmuştur. Buna göre, Kanun'da yatırımcı kavramı yanı sıra, büyük yatırımcı kavramına da yer verilmiştir.

\section{aaa. Yatırımcl}

Girişimcilik Kanunu madde 274/2'de yatırımcı: "Kazakistan Cumhuriyeti'ne yatırım yapan gerçek ve tüzel kişiler" olarak tanımlanmıştır. Madde hükmünden de anlaşıldığı üzere, kanun koyucu, yerli-yabancı ayrımı gözetmeksizin, her iki yatırımcıyı da aynı statüye tabi tutmuştur.

\section{bbb. Büyük Yatırımcl}

Kanunun madde 274/4 uyarınca, büyük yatırımc1: "Kazakistan Cumhuriyeti'nde en az aylık hesaplanan göstergenin ${ }^{118}$ iki milyon katı kadar yatırım yapan gerçek ve tüzel kişi ${ }^{\prime}{ }^{1 i{ }^{119}}{ }^{19}$. Hükümden de anlaş1ldığ1 üzere, Kazakistan' da büyük yatırımcı olarak faaliyette bulunmak için belli miktarda yatırım yapmak gerekmektedir. Bahsi geçen miktarın altında yatırımın söz konusu olduğu durumlarda, yalnızca yatırımcıdan bahsedilecektir.

117 Moroz, s. 48. Ayrıca, mülga 2003 tarihli Kanunda da sınai ve fikri mülkiyet hakları yatırımlar kapsamından çıkarılmış idi (m.1/1). Oysaki mülga 1994 tarihli "Yabancı Yatırımlar Kanunu'nda, "yatırım" tabiri sınai ve fikri mülkiyet haklarını da kapsamaktaydı ("Yabanc1 Yatırımlar Kanunu", m. 1/1).

118 Aylık hesaplanan gösterge her sene değişmektedir; 2019 y1lı için bu gösterge 2.525 Tenge (Tenge-Kazakistan Cumhuriyeti para birimi) olarak belirtilmiştir (закон Республики Казахстан от 30 ноября 2018 года № 197-VI "О республиканском бюджете на 2019-2021 годы”. Dolayısıyla, büyük yatırımcı olarak kabul edilen yat1rımcının 2019 yılında en az 5.050.000 000 milyar Kazakistan Tengesi olarak yatırım yapması gerekmektedir (yaklaşık 13.350.000 milyon ABD Doları; 14 Şubat 2019 itibariyle güncel döviz kuru: 1 ABD Dolar1-378,28 Tenge).

119 Mülga 2003 tarihli Kanun madde 1/17. 
Burada oluşabilecek muhtemel sorulardan biri de: Kanunda yatırımcl ile büyük yatırımcı statüleri arasında her hangi bir farkın olup olmadığıdır? Aşağıda da görüleceği üzere, yatırımlardan kaynaklanan uyuşmazlığın taraflarından yatırımcı $\mathrm{m} 1$ yoksa büyük yatırımcı $\mathrm{m} ı$ olduğunun tespiti üzerine, bu iki yatırımcı arasında uyuşmazlığın çözümü bakımından ciddi bir farklılıktan söz etmek mümkün olabilmektedir.

\section{cc. Yatırım Uyuşmazlıklarının Çözümü}

\section{aaa. Yatırımcı Bakımından}

Yatırım uyuşmazlıklarının çözümüne ilişkin hükümler Girişimcilik Kanunu'nun 296. maddesinde yer almaktadır. Bu maddeye göre:

1. Yatırım uyuşmazlı̆̆ı, yatırımcı ile büyük yatırımcının ev sahibi ülke ile akdettikleri yatırım anlaşmasından doğan uyuşmazlıktır.

2. Yatırım uyuşmazlıkları, karşıllılı görüşmeler veya tarafların önceden belirlemiş olduğu prosedüre uyularak çözümlenmektedir.

3. Yatırım uyuşmazliklarının, 296. maddenin 1. fikrasina göre çözümü mümkün olmadiğı durumlarda, uluslararası sözleşmeler ile Kazakistan Cumhuriyeti kanunlarina uygun olarak, Kazakistan Cumhuriyeti mahkemeleri yanı sira, tarafların anlaşması ile belirlenen tahkim ${ }^{120}$ mahkemelerinde de çözüm yollarına başvurulabilir.

4. Yatırımla ilgili olmayan uyuşmazlıklar, Kazakistan Cumhuriyeti mevzuatına göre çözümlenmektedir.

120 Burada belirtmek gerekir ki, Kazakistan'da yatırım uyuşmazlıkları ile ilgili davalar, genellikle, tahkime götürülmektedir, zira taraflardan biri ev sahibi devlet olunca, yatırımcı tahkimi tercih etmektedir. Örneğin, Stockholm Ticaret Odası tahkim Enstitüsü'nde (SCC) açılan CCL v. Republic of Kazakhstan davası (Case 122/2001), imtiyaz sözleşme-sinden kaynaklanmış ve davacı CCL firması, haklarının, Kazakistan Devleti tarafından sınırlandırıldığını ve yatırımlarına el konulduğunu öne sürerek, tahkim şartına istinaden SCC Tahkim Merkezine başvurmuş ve fakat davayı kazanamamıştır; bkz. https://www.italaw.com/sites/default/files/case-documents/ita0289_1.pdf Erişim 14.02.2019; ayrica bkz. Betaneli, Ketevan: “Арбитражные Дела в Нефтегазовой Отрасли с Үчастием Казахстана" (Arbitrajne Dela v Neftegazovoy Otrasli s Uchastiem Kazahstana), https://online.zakon.kz/Document/?doc_id=35883129\#pos=6;-155 Erişim 14.02.2019; ya da SCC tahkim Merkezi'nde Kazakistan aleyhine sonuçlanan yine imtiyaz sözleşmesinden kaynaklanan benzer nitelikli Anatolie Stati, Gabriel Stati, Ascom Group SA and Terra Raf Trans Traiding Ltd v. Republic of Kazakhstan (SCC Case V 116/2010) vb; bkz. Betaneli, https://online.zakon.kz/Document/?doc_id=35883129 \#pos=6;-155 Erişim 14.02.2019. 
Mülga 2003 tarihli Kanunda olduğu gibi, yeni Kanunda da uyuşmazlıklar iki gruba ayrılmaktadır:

1. Yatırım uyuşmazlıkları;

2. Yatırımla ilgili olmayan uyuşmazlıklar.

Yatırım uyuşmazlıklarının tanımı, yukarıda da belirtildiği üzere, Girişimcilik Kanunu'nun 296. maddesi 1. fikrasında yer almaktadır. Madde metninde ikinci grup uyuşmazlıklar, yani yatırımla ilgili olmayan uyuşmazlıklar, açıklığa kavuşturulmamıştır ${ }^{121}$. Bu durumda Moroz'un tespiti doğrultusunda, yatırım uyuşmazlıklarının tanımından yola çıkılırsa, bu tanımın dışında kalan uyuşmazlıkların yatırımla ilgili olmayan uyuşmazlıklar olarak değerlendirilebileceğini ${ }^{122}$ söyleyebiliriz.

\section{bbb. Büyük Yatırımcı Bakımından}

Yatırım faaliyetinden doğan uyuşmazlığın taraflarından biri büyük yatırımcı ise, uyuşmazlığın çözümü farklı bir usule tabi tutulmaktadır.

Konu ile ilgili Kazakistan Cumhuriyeti 377-V sayılı ve 2015 tarihli yeni Medeni Usul Kanunu ${ }^{123}$ madde 28'de Yüksek Mahkemenin yetkisi düzenlenmiş ve maddenin ikinci fikrasında şu hükme yer verilmiştir: "2) Yüksek Mahkeme, büyük yatırımcının taraf olduğu yatırım uyuşmazlıklarında ilk derece mahkemesi sifatıyla görev yapmaktadır".

Hüküm uyarınca kanun koyucu, getirmiş olduğu yeni kuralla büyük yatırımcıya ayrıcalık ${ }^{124}$ tanımıştır. Böyle bir hükmün getirilmesindeki amaç, kanaatimizce, yatırımlara ihtiyaç duyan Kazakistan'da güvenli yatırım ortamının sağlanmasının yanı sıra, ülkeye büyük çaptaki yatırımların akışını da sağlamaktır ${ }^{125}$.

121 Mülga 2003 tarihli Kanunda da bu durum açıklığa kavuşturulmamış idi. Ancak mülga 1994 tarihli "Yabancı Yatırımlar Kanunu yatırımla ilgili olmayan uyuşmazlıklara 27'nci maddenin 7. fikrasında yer vererek, şöyle tanımlamaktaydı: "Yabancl yatırımcı ile Kazakistan Cumhuriyeti gerçek, tüzel kişiler ve devlet kurumları arasında çıkan ve fakat yatırımla ilgili olmayan uyuşmazlıklar".

122 Moroz, s. 46.

123 Казахстанская правда (Kazahstanskaya Pravda), 03.11. 2015 г., № 210 -28086.

124 Mülga 2003 tarihli Yatırımlar Kanunu 9.madde hükmünde yatırım uyuşmazlıklarının çözümü bakımından, ayrım gözetilmeksizin aynı mekanizma öngörülmüş idi. Bu mekanizma, üst başlıkta belirtilmiş olan Girişimcilik Kanununun 296.maddesi 2 ve 3.fikralarında yer alan kurallara tabi idi.

125 Kazakistan Ulusal Bankası, Kazakistan'da 2016 yılında doğrudan yabancı yatırımların 20,6 milyar dolara ulaştığını, 2015'e kıyasla yüzde 40'lık artış görüldüğünü bildirdi; http://www.memleket.com.tr/kazakistanda-dogrudan-yatirim-yuzde-40-artti-1094424h 
Ayrıca belirtmek gerekir ki, büyük yatırımcıların ${ }^{126}$ taraf olduğu yatırım uyuşmazlıklarının Yüksek Mahkemece çözüme kavuşturulması bakımından konu ile ilgili gerekli bilgi ve niteliklere sahip hâkim heyeti kurulmuştur. Aynı zamanda Yüksek Mahkeme bünyesinde yatırım alanında uzmanlaşmış yerli ve yabancı hukukçu ve bilim adamlarından oluşan 12 kişilik Uluslararası Danışma Kurulu ${ }^{127}$ da faaliyete başlamıştır ${ }^{128}$.

Ayrıca, ülkede hem yatırımcı hem de büyük yatırımcıların menfaatleri iç hukuk kuralları yanı sıra, ileride bahsedileceği üzere, Kazakistan Devletinin taraf olduğu uluslararası sözleşmelerle de korunmaktadır.

\section{dd. Girişimcilik Kanunu'nda Yer Alan Diğer Esaslar}

Girişimcilik Kanunu'nun yatırımı düzenleyen maddelerinde aşağıdaki esaslar da yer almaktadir:

1. Kazakistan Cumhuriyeti sinırlarında yatırımcı faaliyetinin hukuken korunmasının garantisi: Yatırımcıların hakları ve menfaatleri tam ve mutlak olarak Anayasa, Girişimcilik Kanunu, Kazakistan Cumhuriyeti'nin diğer kanunları ve Kazakistan Cumhuriyeti'nin onayladığ1 uluslararası sözleşmelerle korunmaktadir (m. 276/1).

2. Medeni hukuk kuralları uyarınca yatırımcının zararlarını tazmin hakkl: Yatırımcılar, Kazakistan Cumhuriyeti kanunlarına aykırı olarak devlet kurumları tarafindan alınan kararlar veya bu kurum yetkililerinin kanuna aykırı eylemleri (veya kayıtsız kalmaları) sonucunda oluşacak zararlar bakımından Kazakistan Cumhuriyeti kanunlarına göre tazmin hakkına sahiptir (m. 276/2).

3. Yatırımciya gelir kullanma garantisi: Yatırımcılar, Kazakistan Cumhuriyeti kanunlarına göre vergi ve bütçeye ilişkin ödemeler ile diğer gerekli

Erişim tarihi 24.11.2017. Ayrıca, 2017 yılının ilk üç ayında da ülkeye yapılan yabancı yatırımlarda artış kaydedilmiştir; http://rfcaratings.kz/6579 Erişim 27.11. 2017.

126 Kanaatimizce, büyük yatırımcı bakımından Kanunda belirtilmiş yatırım miktarının düşürülmesi ile ülkede büyük yatırımcı olanaklarından daha çok yatırımcının istifade etmesi, yabancı yatırımların teşvikinde etkili olabilirdi.

127 Danışma Kurulu 15.02.2016 tarihinde Kazakistan Cumhurbaşkanı Nursultan Nazarbayev'in "100 Adım” başlıklı Stratejik Programı çerçevesinde kurulmuştur; https://bnews.kz/ru/live/conference/sudebnaya_zashchita_investitsii_v_kazahstane2016_06_06-4902 Erişim 31.10.2017.

128 Yatırımciların korunmas1, http://e-law.kz/sovety/13-blog/72-zashchita-investorov.html Erișim 31.10.2017. 
ödemeleri yaptıktan sonra, yatırım faaliyeti neticesinde elde edilen geliri, kendi isteğine göre kullanma hakkına sahip olacaktır (m. 277) ${ }^{129}$.

4. Devletleştirme ve istimlâk durumunda yatırımcı haklarının korunmast: Mülga Yatırımlar Kanunu'nda olduğu gibi (m.8), Girişimcilik Kanunu'nun 279. maddesinde aşağıdaki hükümler yer almıştır:

a. Kamu ihtiyaçları gereğince Kazakistan Cumhuriyeti kanunlarında belirtilen istisnai durumlarda, yatırımcının malvarlığı devletleştirilebilir ve istimlâk edilebilir.

b. Devletleştirme durumunda yatırımcının ülke kanunlarına göre bütün zararları tazmin edilmektedir.

c. Yatırımcının mallarının istimlâk edilmesi, malın piyasa değerinin ödenmesi şeklinde yapilır.

d. İstimlâk edilen mal için ödenen bedelle ilgili olarak mülk sahibi mahkemede dava açma hakkına sahiptir.

e. İstimlâka yol açan hallerin ortadan kalkması durumunda yatırımcı, malların fiyatının düşmesinden ortaya çıkan zararı dikkate alarak, tazminatı için ödenen bedeli iade etmek şartıyla, kalan mallarının geri verilmesini talep etme hakkına sahiptir (m. 279/5) ${ }^{130}$.

f. Ekonominin öncelikli sektörlerine yapılacak yatırımlar için yeni vergi ve gümrük muafiyetleri getirilmiştir $(\mathrm{m} .283)^{131}$.

\section{ee. Yatırımla İlgili Ayrıcalıklar}

Girişimcilik Kanunu ile yatırımcılara aşağıdaki ayrıcalıklar da sağlanmaktadır:

1. Yatırım vergi muafiyeti (m. 290) ${ }^{132}$;

2. Gümrük vergi muafiyeti (m. 287) ${ }^{133}$;

3. Devletin ayni yardımı (m.288) ${ }^{134}$.

129 Aynı hüküm mülga 2003 tarihli Kanunun 5.maddesinde de yer almakla birlikte, 1994 Kanun'daki benzer hüküm şu şekilde düzenlenmişti: "Yabancı yatırımcılar, faaliyetlerinden elde ettikleri geliri Kazakistan Cumhuriyeti topraklarında yeni bir yatırım için, mal alımı için ve mevzuat tarafından yasaklanmayan herhangi bir amaç için kullanma hakkına sahiptirler" (m. 10).

1301994 tarihli Kanunda İstimlâk edilen mal için ödenen bedelle ilgili madde 7'de, istimlâkın sona ermesi durumunda geri kalan malını isteme hakkından bahsedilmemiştir.

131 Mülga 2003 tarihli Kanun madde 17.

132 Mülga 2003 tarihli Kanun madde 16.

133 Mülga 2003 tarihli Kanun madde 17.

134 Mülga 2003 tarihli Kanun, madde 18. 
Ancak belirtmek gerekir ki yatırım ayrıcalıkları, Kanun'un madde 285 uyarınca, Kazakistan Hükümeti tarafından belirlenen öncelikli sektörlerde faaliyette bulunan yatırımcılara sağlanmaktadır. Öncelikli sektörler listesi ise, Kazakistan Hükümeti tarafından 14 Ocak 2016 tarihli 13 sayılı Kararla onaylanmıştır ${ }^{135}$.

Kazakistan doktrininde yatırım ayrıcalıklarıyla ilgili iki farklı görüşe rastlanmaktadır. Birinci görüşe göre yatırım ayrıcalıkları, Kazakistan Cumhuriyeti sınırlarında faaliyette bulunan yatırımcılara sağlanan garantiler olarak değerlendirilmektedir ${ }^{136}$. Ancak, bizim de katıldığımız ikinci görüş doğrultusunda ise ayrıcalıklar, yatırımcılara sağlanan garanti özelliklerini taş1mamaktadır. Zira yatırım mevzuatına göre garantiler, Kazakistan Cumhuriyeti sınırlarında faaliyette bulunan tüm yatırımcılara sağlanmaktadır. Yatırım ayrıcalıkları ise, yine yatırım mevzuatına göre Hükümet tarafından belirlenmiş olan öncelikli sektörlere yatırım yapan belli yatırımcılara Yatırım Komitesi tarafindan uygulanmaktadır ${ }^{137}$.

Girişimcilik Kanunu dışında Kazakistan'da yatırımlara ilişkin hükümlerin 7 Aralık 2015 tarihli ve 438-V sayılı "Uluslararası Finans Merkezi (UFM) Astana Hakkında Kanunda ${ }^{138}$ da yer aldığını söylemek mümkün olacaktır. Bu nedenle, aşağıda ana hatlarıyla UFM Astana'da yer alan ve yatırımların teşvikine ilişkin esaslara değinmenin de yerinde olacağ kanaatindeyiz.

135 Kazakistan Hükümeti tarafindan öncelikli sektörler olarak belirlenen sektörler (sadece başlık olarak verilmektedir): Tarım; Ormancılık ve bu alandaki hizmet; Balıkçılık, balık yetiştiriciliği ve bu alanlarda hizmet; Gıda ürünleri üretimi; Matbaacıllı faaliyeti ve bu alandaki hizmet; Petrol ürünleri üretimi; Kimya sanayii; Lastik ve plastik ürünlerin üretimi; Diğer metal olmayan mineral ürünlerin üretimi (cam ve cam ürünlerinin üretimi); İnşaat; Hotel ve Restoranlarca hizmet verilmesi; Karayolları araçlarının faaliyeti; Su araçlarının faaliyeti; Hava araçlarının faaliyeti; Araba, romork ve yarı romork üretimi; Diğer ulaştırma araçlarının üretimi; İkincil hammadde işlenmesi (metal olmayan artıklar ve hurda işlenmesi); Enerji, gaz, buhar ve su üretimi; Suyun toplanması, temizlenmesi ve dağıtımı; Tekstil üretimi; Giyim üretimi; Deri ayakkabı üretimi; Metalurji sanayii; Hazır metal ürünlerinin üretimi; Makine ve teçhizat üretimi; Elektrik makineleri ve elektrik teçhizatının üretimi; Radyo, televizyon ve iletişim için aygıt üretimi; tıbbi teçhizat, ölçme araçları, optik aletler ve aygıtların üretimi; Eğitim; Sağlık ve sosyal hizmetler; Kültür ve spor organizasyonuyla ilgili faaliyet gibi birçok alan daha belirtilmiştir.

136 Taimova, Mirgul: Гарантии Иностранным Инвесторам по Законодательству Республики Казахстан (Garantii İnostrannım İnvestoram po Zakonodatelstvu Respubliki Kazakhstan), Almat1, 1999, s. 82-83.

137 Maulenov, 2000, s. 347.

138 Ведомости Парламента Республики Казахстан (Vedomosti Parlamenta Respubliki Kazahstan), 2015 г., № 24, ст. 175. Bundan sonra kısaca UFM Astana olarak anılacaktır. 


\section{d. Uluslararası Finans Merkezi Astana Hakkında Kanun}

Kazakistan Cumhuriyeti'nin yatırımlar mevzuatı çerçevesinde UFM Astana'nın da değerlendirilebileceğini yukarıda belirtmiştik. Zira bahsi geçen Kanunun amacı, ülkeye, özellikle, yabancı yatırımları çekerek, Finans Merkezi Astana'y1 uluslararası finans merkezi haline getirmektir.

UFM Astana Kanunu'nun kabulü ile Kazakistan'ın başkenti Astana' $\mathrm{da}^{139}$ kesin olarak işaretlenmiş sınırları ile ayrı bir hukuki rejime tabi Finans Merkezi Astana ${ }^{140}$ adı altında bir bölge oluşturulmaktadır (m.1/1). Bu böl-gede Kazakistan Cumhuriyeti yasaları uygulanmamakta, zira birincil olarak bölgenin kendi hukuki düzenlemeleri (m.4/1), ikincil olarak da İngiltere ve Galler yasaları uygulanacaktır (m.4/2).

$\mathrm{Bu}$ noktada UFM Astana Kanunu bazı yazarlarca haklı olarak eleştirilmektedir ${ }^{141}$, zira bir bağımsız devletin siyasi sınırları içerisinde başka bir devlet hukukunun uygulanması Anayasaya aykırı olduğu gibi, devletin bağımsızlık prensibi ile de bağdaşmamaktadır. Ayrıca, Merkezin resmi dili de İngilizcedir (m.15).

Bunun yanı sira, Merkezin yarg1 organları, Kazakistan Cumhuriyeti yargı sistemine dâhil edilmemiş ve ilk derece ile istinaf mahkemelerinden oluşmakla birlikte, istinaf mahkeme kararlarının kesin olduğu belirtilmiştir (m.13/2,3). Böylece Merkez mahkemeleri, ceza ve idari davaları haricinde, diğer tüm hukuk davaları bakımından yetkilidir (m.13/4) ve yargı dili de İngilizcedir. Ancak tarafların talebi üzerine, duruşma esnasında Rusça ve Kazakçaya da çeviri yapılabilmektedir (m.19).

Ayrıca taraflar, uyuşmazlığın çözümü bakımından tahkime gitme hususunda aralarında anlaşmışlar ise, bu durumda uyuşmazlık milletlerarası tahkimde de görülebilecektir (m.14).

Peki, Merkezin yatırımcı ve girişimciler bakımından cazip hale gelmesi için Kanunda ne gibi ayrıcalıklara yer verilmiştir? Burada çok önemli birkaç ayrıcalığa değinmekte yarar vardır.

Birincisi, Merkezde faaliyette bulunan girişimci ve yatırımcıların bazı vergilerden 1 Ocak 2066 yılına kadar muaf tutulacağı hüküm altına alınmış$\operatorname{tir}(\mathrm{m} .6 / 3)$.

139 Kazakistan'ın başkenti Astana'nın adı, Cumhurbaşkanı'nın 23 Mart 2019 tarihli 6 nolu Kararı ile "Nur-Sultan" (Нур-Султан) olarak değişmiştir (Указ Президента Республики Казахстан от 23 марта 2019 года № 6).

140 Bundan sonra kisaca Merkez olarak anılacaktır.

141 Suleymenov, s. 1. 
İkincisi, Merkezde faaliyette bulunmak ve Merkez kurumlarında çalışmak için gelen yabancılara beş yıllık süre ile vize verilmektedir (m.7/2). Ayrıca Merkezde çalışacak veya Merkez sınırları içerisinde faaliyette bulunacak olan yabancıların çalışma izninden muaf tutulacağ 1 da hüküm altına alınmıştır (m.8/2).

Bunun yanı sıra, yukarıda da bahsedildiği üzere, Merkezin resmi dilinin İngilizce olmas1, faaliyette bulunacak yabancılar için de büyük bir avantajdir.

Son olarak belirtmek gerekir ki, eleştirilere rağmen, getirilmiş yeni düzenleme ile yabancı yatırımcılar bakımından Merkezin cazip olduğunu söylemek mümkün olacaktır.

\section{ULUSLARARASI DÜZEYDE YABANCI YATIRIMLARIN TEŞVİKi}

Yabancı yatırımlara ihtiyaç duyan Türkiye ve Kazakistan, taraf oldukları milletlerarası sözleşmelerle de yabancı yatırımcılara uluslararası düzeyde güvence vererek yatırımların teşvikini sağlamaktadır.

Yatırımların iki ve çok taraflı sözleşmelerle ${ }^{142}$ korunması, yatırım yapan ve yapılan devletler ile vatandaşları açısından bir ihtiyaca cevap vermekte ve bu yönde önemli yararlar hedeflenmektedir. Zira yabancı sermayenin teşviki mevzuatı, anılan sermayenin gelişini ve çalışma şartlarını düzenlemektedir. Yatırımların korunması ile ilgili milletlerarası sözleşmeler ise yatırımları ticari olmayan risklere karşı da koruyarak, yabancı yatırımları özendirmeye yöneliktir ${ }^{143}$.

Bilindiği üzere, milletlerarası sözleşmeler, uluslararası hukuk sisteminde büyük öneme sahiptir. Bunun en iyi göstergesi de, birçok ülkenin Anayasasında $^{144}$ milletlerarası sözleşmelere ulusal kanunların karşısında üstünlük sağlanmasıdır ${ }^{145}$.

$\mathrm{Bu}$ bağlamda aşağıda yabancı yatırımlarla ilgili Türkiye ve Kazakistan'ın akdetmiş olduğu iki ve çok taraflı sözleşmelere de yer verilecektir.

142 Çalışmamızda sözleşme kavramı yanı sıra, anlaşma kavramına da yer verilmiştir.

143 Tekinalp, s. 176; Farhutdinov, İ. Z.: “Действие международных Договоров в Сфере Иностранных Инвестиций” (Deystviye Mejdunarodnıh Dogovorov v Sfere İnostrannıh İnvestitsiy), Trudı Moskovskoy Gosudarstvennoy Yuridiçeskoy Akademii, Moskva, 1999, no: 5, s. 135-136.

144 Bkz. Türkiye Cumhuriyeti Anayasası, m.90; Kazakistan Cumhuriyeti Anayasası, m.4/3.

145 Farhutdinov, s. 135. 


\section{A. Çok Taraflı Milletlerarası Sözleşmeler}

Bu başlık altında Türkiye ${ }^{146}$ ve Kazakistan' ${ }^{147}$ taraf olduğu ve yatırım alanında büyük öneme sahip çok taraflı milletlerarası sözleşmelere değinilecek ve akabinde ikili sözleşmelerden de bahsedilecektir. Dünya Bankası öncülüğünde ve özellikle gelişmekte (kalkınmakta) olan ülkeler göz önünde bulundurularak hazırlanmış olan çok taraflı sözleşmelerden birincisi, "Çok Taraflı Yatırım Garanti Kuruluşu Sözleşmesi" (Multilateral Investment Guarantee Agency-MIGA) ${ }^{148}$, diğeri ise "Devletler ve Diğer Devletlerin Vatandaşları Arasındaki Yatırım Uyuşmazlıklarının Çözülmesi Hakkında Sözleşmedir (International Center for the Settlement of Investment Disputes-

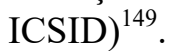

\section{1. Çok Taraflı Yatırım Garanti Kuruluşu Sözleşmesi (MIGA)}

Çok Taraflı Yatırım Garanti Kuruluşu Sözleşmesi (MIGA) ${ }^{150}$ Ekim 1985'te Seul'da imzalanmıştır. Kısaca MIGA olarak da anılan Sözleşmede öngörülen hukuki işlemleri yapmak üzere, Çok Taraflı Yatırım Kuruluşu olarak adlandırılan bir kuruluş tesis edilmiştir. Uluslararası İmar ve Kalkınma Bankası (Dünya Bankası) Grubunun bir üyesi olan Kuruluş, tüzel kişiliğe sahip uluslararası bir kuruluş olarak sözleşme yapmaya, taşınır ve taşınmaz mal alıp satmaya ve hukuki işlemleri yapmaya yetkili kılınmıştır. Bu Sözleşme, Dünya Bankası'na üye olan devletlerin ve İsviçre'nin üyeliğine açıktır. Kuruluşun merkezi Washington 'dadır ${ }^{151}$.

146 Bkz. RG: 6.12.1988-20011.

147 Zakon Respubliki Kazakhstan ot 26.07.1992 “O Çlenstve Respubliki Kazakhstan v Mnogostoronnem Agentstve po Garantiyam İnvestitsiy (MIGA) i Mejdunarodnom Tsentre po Uregulirovaniyu İnvestitsionnı Sporov (ICSID), Ведомости Верховного Совета Республики Казахстан, (Vedomosti Verhovnogo Soveta Respubliki Kazahstan) 1992, No:13-14, ст. 311.

148 Bundan sonra kisaca MIGA diye anılacaktır.

149 Bundan sonra kisaca ICSID diye anılacaktır.

150 Sözleşme metni için bkz. RG: 6.12.1988-20011; MIGA Sözleşmesine toplam 181 ülke taraftır; https://www.miga.org/who-we-are/member-countries/ Erişim tarihi 17.05.2017.

151 Çelikel/Öztekin Gelgel, s. 187; Tekinalp, s. 176; Sattarova, G.: Право и Иностранные Инвестиции в Республике Казахстан (Pravo i İnostrannye İnvestitsii v Respublike Kazakhstan), Almaty, 1997, s. 103; Doronina, N. G./Semilyutina, N. G.: “Защита Иностранных Инвестиций и Российское Законодательство” (Mnogostoronniye Mejdunarodnıye Konventsii v Oblasti Zaşitı İnostrannıh İnvestitsiy i Rossiyskoye Zakonodatelstvo), Gosudarstvo i Pravo, 1992, no. 10, s. 90; Veselkova, E. E.: "Некоторые Правовые Аспекты Соглашений по Защите Инвестиций" (Nekotorıye Pravoviye Aspektı Soglaşeniy po Zaşite İnvestitsiy), Zakon i Pravo, no: 10, 2002, s. 53. 


\section{a. Kuruluşun Amact}

MIGA'nın kuruluş amacı, Sözleşme'nin 2.maddesinde ifade edilmiştir. Buna göre Kuruluşun amacı, gelişmekte olanlar başta olmak üzere, üye ülkelere yönelik yatırımların akışını sağlamaktır. Bunun için Kuruluş, üye ülke yatırımcılarına, diğer üye ülkelerdeki yatırımları sebebiyle uğrayabilecekleri ticari olmayan risklere karşı mükerrer ve ortak sigortalamalar da dâhil olmak üzere, teminat sağlayacaktır. Ayrıca Kuruluş, gelişmekte olan üye ülkelere yabancı sermaye akışını sağlamak için gerekli çalışmaları da yürütecektir.

Yabancı yatırımların ticari olmayan risklere karşı çok taraflı sözleşme ile korunması, yabancı yatırımcılara güven vermekle birlikte, gelişmekte olan ülkelere yatırım yapmalarını da teşvik etmektedir ${ }^{152}$. Bu bakımdan MIGA Sözleşmesinin yatırım alanında çok önemli bir belge olduğunun altını bir kez daha çizmekte yarar vardır.

Özetlemek gerekirse, MIGA, yatırımcılara bir üye ülkedeki yatırımları nedeniyle maruz kalabilecekleri ticari olmayan risklere karşı teminatın sağlanması yanı sıra, gelişmekte olan ülkelere yatırım yapmaya ilişkin yatırımc1lardaki tereddütleri gidermeyi de amaçlamaktadır ${ }^{153}$.

$\mathrm{Bu}$ amaca ulaşmak için Kuruluş, Sözleşmenin 2. maddesinde belirtilen şu faaliyetleri yürütür:

- Diğer üye ülkelere, bir ülkedeki yatırımları nedeniyle maruz kalabilecekleri ticari olmayan risklere karşı, mükerrer ve ortak sigortalamalar da dâhil olmak üzere, garanti verir;

- Yatırımların gelişmekte olan üye ülkelere yöneltmek ve bunlar arasında akışını geliştirmek için tamamlayıcı uygun çalışmaları yapabilir;

- Hedefine ulaşmada gerekli olabilecek veya istenebilecek diğer benzer yetkileri kullanır.

Faaliyetlerini büyük ölçüde gelişmekte olan ülkelerin üzerinde yoğunlaştıran Kuruluşun, bundan dolayı zaman zaman gelişmiş ülkelerin eleştirilerine de maruz kaldığı görülmektedir. Ancak Kuruluşun MIGA'nın amacına uygun hareket ettiği dikkate alınırsa, eleştirilerin yerinde olmadığını söylemek mümkün olacaktır ${ }^{154}$.

152 Çelikel/(Öztekin) Gelgel, s. 185; Farhutdinov, s. 16.

153 Arkan Akbıyık, Azra: "Çok Taraflı Yatırım Garanti Kuruluşu”, Ünal Tekinalp'e Armağan, Beta, İstanbul, 2003, s. 158-159.

154 Kırlı Aydemir, Deniz: Çok Taraflı Yatırım Garanti Kuruluşu (MIGA) ve Yabancı Yatırımların Politik Risklere Karşı Korunması, Legal, İstanbul, 2005, s. 119. 
Kuruluş, Guvernörler Konsey’i, Yönetim Kurulu, Başkan ve kuruluşun belirlediği işleri yapacak personelden oluşur (m.30). Ayrıca Konsey, Kuruluşun temel organı olarak kabul edilmiştir.

\section{b. MIGA'nın Faaliyet Alanı}

Çok Taraflı Yatırım Garanti Kuruluşu (MIGA)'nın uğraş alanı sigortacılıktır $^{155}$. Sigorta sözleşmesi yapmak, bir ticari işletmenin mali risklere karşı başvurduğu etkin önlemlerden biridir ${ }^{156}$.

MIGA'nın garanti kapsamına girilmesi hususunda MIGA ile yatırımcı arasında bir garanti sözleşmesinin ${ }^{157}$ yapılması gerekmektedir. Garanti sözleşmesinde garanti sahibinin, yatırım yapılan projenin, yatırımın mahiyetinin, garanti kapsamına giren risklerin, garanti şartlarının ve ev sahibi ülke ile yatırımcı arasındaki diğer her türlü anlaşmaların tanımı yapılmaktadır. Ayrıca, garanti sözleşmesinde MIGA'nın ve garanti sahibi yatırımcının hakları ve borçları da belirlenmektedir ${ }^{158}$.

Sözleşmenin "Rücu" başlıklı 18/a. maddesine göre: "Kuruluşun garanti sahibine, tazminat ödemesi veya ödemeyi kabul etmesinden sonra Garanti

155 Sattarova, s. 104.

156 Aksel, A. E.: Risk Yönetim Aracı Olarak Futures Piyasaları Yapısı. İşleyiş Mekanizmaları ve Bazı Ülke Örnekleri, Sermaye Piyasası Kurulu Yayın No: 21, Ankara, 1995, s. 26, (Naklen: Kubilay, Huriye: Uygulamalı Özel Sigorta Hukuku, Barış Yayınları, 2. Bask1, İzmir, 2003, s. 3).

157 Burada yatırımcı ile Kuruluş arasında yapılan sözleşmenin hukuki niteliği üzerinde de durulmalıdır. Her ne kadar Kuruluşun adı "Çok Taraflı Yatırım Garanti Kuruluşu (MIGA)" olsa da, MIGA ile yatırımcı arasındaki sözleşme garanti sözleşmesi olarak nitelendirilse de, doktrinde bazı yazarlarca bu sözleşmenin hukuki niteliği itibariyle garanti sözleşmesi kapsamında değil de, bilakis sigorta sözleşmesi kapsamında değerlendirilmesi gerektiğine dikkat çekilmektedir; Herdegen, M.: Internationales Wirtschaftsrecht, 2.Aufl., München, 1995, \$19 N.11 (Naklen Arkan Akbıyık, s. 162); Frolkina, E. N.: "Правовое Регулирование Страхования Иностранных Инвестиций в Международном Частном Праве" (Pravovoe Regulirovanie Strahovaniya İnostrannıh İnvestitsiy v Mejdunarodnom Chastnom Prave), Законы России, No:6, Haziran, 2012, s. 90; Labin, D. K.: Международное Право по Защите и Поощрению Иностранных Инвестиций (Mejdunarodnoe Pravo po Zashite i Pooshreniyu İnostrannıh İnvestitsiy), Wolters Kluwer, Moskva, 2008, s. 112; Garanti sözleşmeleri de, sigorta sözleşmeleri gibi, tazminat sözleşmelerinden olmakla birlikte, sigorta sözleşmesi iki tarafa borç yükleyen bir sözleşme iken, garanti sözleşmesi, kural olarak, tek tarafa borç yükleyen bir sözleşme niteliğindedir. Sigorta sözleşmesinin amacı prim alma karşılığında rizikoya karşı koymaktır, garanti sözleşmesinin amacı ise garanti alanı belli bu hareket tarzına yöneltmektedir; Kubilay, s. 34-35.

158 Tiryakioğlu, s. 158. 
edilenin ev sahibi ülke ve diğer yükümlüler karşısında bu yatırım nedeniyle sahip olabileceği haklar ve alacaklar Kuruluşa rücu edilecektir. Garanti Sözleşmesi bu tür bir rücunun koşul ve kurallarını tespit edecektir".

Bununla birlikte, Kuruluşun garanti ettiği yatırımlar, uygun yatırımlar niteliğini taşımalıdır (m. 12) ${ }^{159}$. Bunun dişında hem yatırımcıların (m. 13) hem de ev sahibi ülkelerin (m. 14) uygun olması gibi şartlar da aranmaktadır.

Çok Taraflı Yatırım Garanti Kuruluşu her türlü riski teminat altına almamaktadır. Zira Kuruluşun garanti kapsamına aldığı riskler, aşağıda da belirtileceği üzere, ticari olmayan risklerdir.

\section{c. MIGA Garantisinden Yararlanacak Yatırımlar ve Risk Türleri}

MIGA garantilerinden yararlanacak olan yatırımların, Kuruluş tarafindan belirlenen uygunluk kriterlerini taşıması gerekmektedir. Bu kriterler, üye devletlerin üye olabilmek için imzaladığı MIGA Sözleşmesinde belirlenmiştir. Bunlar sermaye yatırımları, sermaye kredileri, doğrudan yatırımlar, bunlar dışında kalan diğer yabancı yatırım türleri ve sermaye yatırımı niteliğinden olmayan yatırım türleri olarak sınıflandırılmıştır.

MIGA garantisi kapsamında olan riskler sadece siyasi risklerdir. Yani kapsanan risklerde kesin surette ticari bir risk olmamalı ve nitelik itibariyle tamamen politik olmalıdır. MIGA dört siyasi riski garanti altına almaktadır. Ancak ev sahibi ülkedeki devalüasyon ve paranın değer kaybetmesi gibi riskler garanti kapsamına dahil değildir, zira bu riskler ticari nitelikteki risklerdir. MIGA Sözleşmesi madde 11'e göre garanti altına alınan siyasi riskler:

a) Döviz Transferi Riskleri,

b) Kamulaştırma ve Benzeri Riskler,

c) Savaş ve İç Kargaşa Riskleri,

d) Sözleşme İhlali Riskleridir.

Her ne kadar MIGA Sözleşmesinin 11.maddesi garanti altına alınan riskleri bu şekilde sıralamışsa da, yukarıda da belirtildiği üzere, MIGA,

159 Uygun yatırımlarla ilgili Sözleşmede 2012 yılında değişiklik yapılmış ve böylece garanti edilen yatırımların kapsamı daha da detaylı olarak ifade edilmiştir; Ayrıca MIGA Sözleşmesinin "Karşılanan Riskler" başlıklı 11.maddesi (b) bölümü aşağıdaki şekilde değiştirilmiştir:” (b) Buna ilaveten, Kurul, özel çoğunlukla, yukarıda (a) bölümünde anılanlar dışındaki birtakım gayri ticari riskleri de kapsayacak şekilde fakat hiçbir durumda paranın değer kaybetmesi riskini üstlenmeksizin, bu Maddenin kapsamının genişletilmesini onaylayabilir". Bkz. RG: 01.02.2012-28191. 
bunların dışında kalan birtakım ticari olmayan riskleri ${ }^{160}$ de belli şartlar altında garanti etmektedir.

Kuruluşun görevlerini yapabilmesi için bazı imtiyaz ve muafiyetlerden yararlanması kabul edilmiştir (m.43-48). Bu imtiyazlardan en dikkat çekeni ise, guvernör, direktör, başkan ve personelinin yargı bağışıklığından yararlanmasidir (m.48).

\section{Devletler ve Diğer Devletlerin Vatandaşları Arasındaki Yatırım Uyuşmazlıklarının Çözümü Hakkında Sözleşme (ICSID)}

Dünya Bankası, Uluslararası Yatırım Uyuşmazlıklarının Çözümü Merkezi (International Center for the Settlement of Investment Disputes (ICSID)) aracılığı ile bir uzlaştırma ve tahkim sistemini uygulamaya koyma kararını almış ve 18 Mart 1965'te Washington'da "ICSID" bir sözleşme ile kurulmuştur. Sözleşme, "Devletler ve Diğer Devletlerin Vatandaşları Arasında Yatırım Uyuşmazlıklarının Çözümü Hakkında Sözleşme veya "ICSID Sözleşmesi"161 olarak da adlandırılmaktadır. Uluslararası tüzel kişiliğe sahip olan Merkez'in yerleşim yeri Dünya Bankası'nın merkezi olan Washington' dur ${ }^{162}$.

Merkez, bir İdari Konsey ve Sekretaryaya sahiptir. Merkezin bünyesinde arabulucular ve hakemler paneli oluşturulmaktadır (m.3).

Çok taraflı ICSID Sözleşmesi ile oluşturulan Merkez ve bu kapsamdaki tahkim, daha özel ve uzman bir tahkim olarak, daha çok tercih edilen bir usul olmuştur ${ }^{163}$.

Merkezin amac1, sözleşmede yer alan hükümler doğrultusunda taraf devletler ile diğer taraf devletlerin vatandaşları arasında yatırımlardan kay-

160 Bkz. dip. 159.

161 Sözleşme metni için bkz: (RG: 6.12.1988-20011); Metinde bundan sonra kısaca "ICSID Sözleşmesi” olarak anılacaktır. ICSID Sözleşmesi'ne 161 ülke taraftır, https://icsid.worldbank.org/en/Pages/about/Database-of-Member-States.aspx Erişim tarihi 12.11.2017.

162 Uludağ, s. 206, Nomer, Ergin/Ekşi, Nuray/Öztekin, Günseli: Milletlerarası Tahkim Hukuku, Beta, 4.Bası, İstanbul, 2013, s. 108; Şanlı, Cemal: Uluslararası Ticari Akitlerin Hazırlanması ve Uyuşmazlıkların Çözüm Yolları, 2 Bası, İstanbul, 2002, s. 384; Akıncı, Ziya: Milletlerarası Ticari Hakem Kararları ve Tenfizi (Hakem Kararları), Ankara, DEÜ Yayınları, Ankara, 1994, s. 102; Maulenov, K. S.: Правовое Регулирование Иностранных Инвестиций в Республике Казахстан (Pravovoye Regulirovaniye İnostrannıh İnvestitsiy v Respublike Kazakhstan), Almatı, 1998, s. 17; Tiryakioğlu, s. 148; Çelikel/(Öztekin) Gelgel, s. 189; Tekinalp, s. 177; Taimova, s. 116.

163 Yımaz, İlhan, s. 31. 
naklanan uyuşmazlıkların uzlaştırma ve tahkim yolu ile çözümü için çalışmaktır (m. 1/2).

Bir uyuşmazlığın ICSID tahkimine sunulabilmesi için gerek kişiler ve gerek konu bakımından belli şartların gerçekleşmesi gerekmektedir. Öncelikle, bu tahkime Sözleşme tarafı ev sahibi devlet ile yine Sözleşme tarafi diğer bir devletin vatandaşı olan yatırımcı arasındaki uyuşmazlıklarda başvurulabilir. İlaveten bu uyuşmazlık, bir yatırımla doğrudan ilişkili bir hukuki uyuşmazlık olmalıdır. Devletin Sözleşmeye taraf olması, tahkimde davalı ya da davacı olabilmesi için yeterli olmamaktadır. Zira ilgili devletin, yatırımdan kaynaklanan uyuşmazlığın tahkim yolu ile çözümüne onay vermiş olması da gereklidir ${ }^{164}$.

ICSID ile ulusal hakem mahkemeleri arasındaki fark, ICSID'ın düzeni ve usulü milletlerarası sözleşme hükümleriyle belirlenmektedir. Ayrıca, ulusal adli ve idari organlar, ICSID'ın faaliyetlerine müdahale etmekte yetkisizdirler ${ }^{165}$.

ICSID'1 diğer hakem mahkemelerinden ayırt eden en önemli fark ise, ICSID'ın kendi adında saklıdır. Şöyle ki, ICSID sadece yatıım anlaşmazlıklarının çözümü için kurulmuştur ${ }^{166}$.

\section{a. Uygulama Alanı}

Uyuşmazlık, ICSID önüne yatırımcı tarafından getirebileceği gibi, ev sahibi ülke tarafından da getirilebilir. Kural bu olmakla beraber, yatırım uyuşmazlıklarının çoğunda davacının yabancı yatırımcı olduğu gözlemlenmektedir ${ }^{167}$.

Yukarıda da kısaca değindiğimiz gibi, uyuşmazlığın ICSID önüne getirilebilmesi için şu şartların gerçekleşmesi gerekmektedir:

1. Uyuşmazlık bir yatırıma ilişkin olmalıdır (m. 25/1). Ancak ICSID Sözleşmesi, yatırım uyuşmazlığından neyin anlaşılması gerektiği hususunda bir tanım vermemektedir. Sattarova'ya göre, ICSID Sözleşmesi'nde yatırım

164 Çelikel/(Öztekin) Gelgel, s. 189; Yılmaz, İlhan, s. 31; Perova, М.: “Международная Форма Регуирования Иностранных Инвестиций” (Mejdunarodnaya Forma Regulirovaniya İnostrannıh İnvestitsiy), Hozyaystvo i Pravo, No: 2, 1999, s. 100.

165 Krupko, S.: "Международный Центр по Урегулированию Инвестиционных Споров" (Mejdunarodniy Tsentr po Uregulirovaniyu İnvestitsionnı Sporov), Hozyaystvo i Pravo, No: 6, 2002, s. 106; Sattarova, s. 94.

166 Şanlı, s. 384; Tekinalp, s. 177; Maulenov, 1998, s. 20.

167 Shıhata, İbrahim: ICSID Arbitration: TheInstitutıon's Point of View, 1993, paragraf 16.02 (naklen Nomer/Ekşi/ Öztekin Gelgel, s 109. 
uyuşmazlığının tanımlanmamasının sebebi, yatırımın akit devletlerin ulusal mevzuatında ${ }^{168}$ tanımlanmış olmasıdır ${ }^{169}$. Şanlı'ya göre ise, yatırım uyuşmazlıklarından neyin kastedildiğini açıkça hükme bağlayan sonraki tarihli ikili anlaşmalar ${ }^{170}$ esas alınarak ${ }^{171}$, "yatırımlardan kaynaklanan hukuki uyuşmazlıklardan" neyin kastedildiği ortaya konulabilir. Buna göre, yatırım uyuşmazlı̆̆l: (a) Devletle diğer devlet vatandaşı yatırımcı gerçek ve tüzel kişiler arasındaki yatırıma ilişkin sözleşme (imtiyaz, istisna, lisans, knowhow vs.)' den kaynaklanan uyuşmazlıklar, (b) Bir tarafın yabancı yatırımlarla ilgili makamının ilgili yatırımcıya sağladığı herhangi bir yatırım müsaadesinin yorum veya uygulamasından doğan uyuşmazlıklar, (c) Bir yatırımla ilgili olarak ve anlaşma ile verilen veya yaratılan herhangi bir hakkın, çiğnendiği iddiasından kaynaklanan uyuşmazlıklardır ${ }^{172}$.

2. Uyuşmazlığın ICSID önüne getirilebilmesi için aranan şartlardan bir diğeri ise gerek ev sahibi ülke, gerek özel yatırımcının mensup olduğu devlet, ICSID Sözleşmesi'ne taraf olmalıdır (m.25/1).

Bundan dolayı da, yatırımcının yatırımını yaptığı ülkenin tabiiyetinde olmaması gereği ortaya çıkmaktadır ${ }^{173}$.

168 Ancak Merkez hakem mahkemeleri bazı davalarda ilgili ulusal mevzuata göre bir yatırımın varlığı ve dolayısıyla Merkezin yetkisinin olup olmadığı sorusu ile karşı karşıya kalmışlardır. Örneğin, "SPP ile Egypt davasında uyuşmazlık, yabancı yatırımcının belli turistik bilgelerin inşası ve geliştirilmesine ilişskin yatırım sözleşmesi imzalanmasından sonra, söz konusu bölgelerin Mısır hükümeti tarafindan kamu alanı ilân edilmesinden doğmuştu. Olayda daha sonra, yabancı yatırımcıya Misır yatırım mevzuatı kapsamında verilmiş olan yatırım izni ve proje iptal edilmiştir. Bunun üzerine yabancı yatırımcı, Misır yatırım mevzuatında ICSID tahkimine onay veren hükümden hareketle Merkezde tahkim davası açmıştır. Mısır, Merkezin yetkisine itirazda, diğerlerinin yanısıra, Merkeze onayı içeren ilgili kanunun bu davada uygulanmayacağını ileri sürmüştür. Zira, ilgili kanunun 1. maddesi kapsamındaki yatırım Mısır yetkili makamınca onaylanmıs (izne bağlanmış) ve yine kanunda belirtilmis alanlardaki faaliyetlerdir. Yabancı yatırımcının ICSID yetkisine onayın içeren mektuptan önce, Mısır söz konusu yatırım iznini iptal etmiş olduğundan, artık kanun kapsamında bir yatırımdan bahsetmek mümkün olmayacaktır. Hakem mahkemesi Misır'ın bu iddiasını geçerli bulmayarak, ilgili Kanuna göre alınmış iznin geçerli olduğunu ve yatırımın bu mevzuata göre gerekli kriterleri haiz olduğunu belirterek, projenin ya da iznin iptalinin ilgili Kanuna göre bir "yatırım” yapılmış olması olgusunu değişstirmediğine karar vermiştir. Sonuçta, ilgili Kanunun bu yatırıma uygulanması sebebiyle Merkezin yetkisine olan onayın varlı̆̆ına hükmetmiştir", Yılmaz, İlhan, s. 174).

169 Sattarova, s. 94.

170 İkili Yatırım Anlaşmaları için bkz. Nomer/Ekşi/Öztekin Gelgel, s. 122 vd.

171 Aynı görüş için bkz. Tiryakioğlu, s. 9, dip. 16.

172 Şanlı, s. 385.

173 Tiryakioğlu, s. 148. 
Ancak birçok olayda ev sahibi ülke, yabancı yatırımcının yerel bir şirket aracılığg ile faaliyette bulunmasını gerekli kılmaktadır. Bu nedenle de söz konusu şartların mevcut olduğu durumlarda, ev sahibi ülkenin tabiiyetini taşıyan bir şirket de ICSID'e başvurabilir. Yatırımeı ve ev sahibi ülke, ICSID çerçevesinde, böyle bir şirketi yabancı bir yatırımcının kontrolü altında ${ }^{174}$ bulunan yabancı bir taraf gibi nazara alma konusunda anlaşmışlarsa, böyle bir başvuru mümkün hale gelmektedir (m. 25/2(b).

Ayrıca, ev sahibi ülke gibi, yatırımcının da ICSID'ın yetkisini kabul etmiş olmas1 gerekmektedir (m.25/1).

Yatırımc1, uyuşmazlık ortaya çıktığında ICSID'e başvurmayı güvence altına almak istiyorsa, ev sahibi ülke yetkili makamları ile yaptığ 1 yatırım sözleşmesinde ICSID'ın yetkisinin kabul edildiğine dair bir kaydın yer alması hususunda 1srar etmekle isabetli davranmış olacaktır ${ }^{175}$.

Ülkeler, ICSID Sözleşmesi'ni onaylayarak, değişik ülkelerle yaptığı iki taraflı yatırım anlaşmazlıklarında da ICSID tahkimine gidilebileceğine ${ }^{176}$ ilişkin hükümlere yer vermektedir.

174 Buna örnek Enron v Argentine davası gösterilebilir. Bu davada ABD'li yatırımcı ile ev sahibi Arjantin arasında yatımla ilgili uyuşmazlık ortaya çıkmıştır. Şöyle ki, davacılar Arjantin'de gaz dağıtımı şirketinin aracılı̆̆ıyla toplam olarak \%35.263'ünün hissedarıdırlar. Uyuşmazlık, bazı Arjantin bölgesel idareleri tarafından özelleştirilen söz konusu gaz dağıtım şirketinin işlemleri üzerinde uygulanan damga vergisi, faiz ve cezalarından doğmuştur. Davacılar, söz konusu vergi uygulamalarının ABD-Arjantin ikili yatırım anlaşmasına aykırı olduğunu iddia ederek, anlaşmaya dayanarak ICSID tahkiminde dava açmıştır. Davada Arjantin, davacıların ilgili Arjantin şirketinde dolaylı olarak yatırımcı olduklarını; azınlık hisseye sahip olmaları ve ilgili şirketin kontrolünün kendilerinde olmadığından bahisle, ilgili şirketlerin bir yatırım olarak değerlendirilemeyeceğini ve davacıların da yatırımcı olmadıklarını ileri sürmüştür. Arjantin, hisselerin ikili yatırım anlaşmasında yatırım olarak değerlendirildiğini kabul ederken, böyle bir halde ancak hisseleri doğrudan etkileyen işlemlerin-kamulaştırma gibi-dava edilebileceğini iddia etmiştir. Davacılar ise, kendilerinin ilgili gaz şirketi adına değil, kendi hisselerinin anlaşma kapsamında yatırım olması sebebiyle, kendi adlarına yatırımeı sıfatı ile dava açtıklarını söylemişlerdir. Hakem mahkemesi kararında, azınlık hissedarların da gerek uluslararası hukuk gerek ICSID sözleşmesi bakımından ilgili şirketlerden ayrı olarak haklarını talep edebilmelerine bir engel olmadığını tespit etmiştir. Yılmaz, İlhan, s. 157158.

175 Tiryakioğlu, s. 149.

176 Bu durum, ülkelerin, sadece ICSID tahkimine gitme konusundaki niyetini gösterir; yoksa bu konuda bir uluslararası yükümlülük doğurmaz. ICSID tahkimine gidilebilmesi için, yatırımla ilgili bir uyuşmazlık çıktıktan sonra, Türkiye'nin ev sahibi ülke sıfatı ile yazılı olarak rızasını vermesi gerekir; Erten, Rıfat: "ICSID Tahkimi”, BATIDER, C. XIX, S. 4, 1998, s. 225. 
3. Aranan şartlardan sonuncusu da ihtilaf taraflarının, ICSID tahkimine gitme konusunda açıkça ve yazılı olarak beyanda bulunmaları gerekmektedir (m.25/1).

Şanlı'ya göre, getirilmiş olan bu sonuncu şart, yani ICSID tahkimine başvuru için ev sahibi devlet ile yabanc1 yatırımcının mensup olduğu devletin Sözleşmeye taraf olmasının yeterli olmamasının yanı sıra, tarafların her somut uyuşmazlıkta karşı1ıklı anlaşmalarının gerekli olması, uygulamada ICSID tahkimine müracaatı azaltmıştır. Bu nedenle devletler, ICSID'ın yargı yetkisini peşinen öngören tahkim klozları içeren iki veya çok taraflı yatırımların korunması ve teşviki anlaşmalarını da akdetmiştir ${ }^{177}$.

\section{b. ICSID Tahkim Merkezi’nin Sağladı̆̆ı Avantajlar}

ICSID tahkimi, diğer tahkimlere nazaran, yatırımcı ile ev sahibi ülkenin menfaatleri arasında bir denge kurulacak şeklinde düzenlenmiştir ${ }^{178}$. Daha açık bir ifade ile ev sahibi ülkede yatırım faaliyetinde bulunmak isteyen yabancı yatırımcının, yatırım yapacağ 1 ülke mahkemelerine karşı güvensizliği veya tereddüdü ICSID tahkimi ${ }^{179}$ ile giderilmiş ve kendisine bir devlete

177 Şanlı, Cemal/Esen, Emre/Ataman Figanmeşe, İnci: Milletlerarası Özel Hukuk, Vedat Kitapçılık, İstanbul, 2016, s. 593.

178 Shıhata, İbrahim: The Experience of the International Center fort he Settlement of Investment Dispites (ICSID) The Arbibral Process and the Independence of Arbitrators, ICC Publications, no: 472, 1991, s. 17 (naklen Nomer/Ekşi/Öztekin Gelgel, s. 109).

179 ICSID Tahkim Merkezi'nde Türkiye ve Kazakistan devletlerinin de taraf olduğu davalar mevcuttur. Bunlardan birkaç örnek vermek gerekirse; örneğin, ICSID Tahkim Merkezi'nde görülen ve Türkiye'nin taraf olduğu Cementownia "Nowa Huta" S.A. v. Republic of Turkey davası, dikkat çeken davalardan biridir (Case No. ARB(AF)/06/2), zira bu davada yatırımcı davacının iyi niyetli olup olmadığı da ele alınmıştır. Mahkeme kararında dava masraflarının davacı tarafından karşılanmasına hükmedilmiş ve fakat Türk Devletinin manevi tazminat talebi kabul edilmemiştir; Bu dava ile ilgili geniş bilgi için bkz. Polat, Malike/Al Kılıç, Şengül: "ICSID Yatırım Tahkimine Konu Olan Cementownia "Nowa Huta" S. A.-Türkiye Uyuşmazlığında "İyi Niyet" ve "Manevi tazminat" İddialarının Değerlendirilmesi", Public and Private International Law Bulletin, Volume: 34, Issue: 2. Yine ICSID Tahkim Merkezi'nde görülen "Tulip Real Estate and Development Netherlands B.V." v. Republic of Turkey (Case No. ARB/11/ 28) davasında mahkeme, yabancı yatırımcı davacının, yeterli süre uzatımı verilmeksizin sözleşmenin haksız olarak feshedildiği ve Türk Devleti'nin müdahalesi ile yatırımlarına el konulduğu iddialarını değerlendirerek, davacının taleplerini reddetmiştir. Bu karar için bkz. https://www.italaw.com/sites/default/files/case-documents/italaw3126.pdf Erişim 13.02.2019. Kazakistan Devleti ile ilgili de aşağıdaki örnekler verilebilir; "Türkiye Petrolleri Anonim Ortaklı̆̆l" (TPAO) v. Republic of Kazakhstan" davasında (Case No. АРБ/11/2), davac1 ТРAO, 14 Ocak 2011 tarihinde Kazakistan devleti aleyhine ICSID'e başvurmuştur. Uyuşmazlık, ortak girişim çerçevesinde petrol arama ve işletmesi ile ilgili olup ve fakat bu dava, 25 Kasım 2013'te tarafların anlaşması ile sulh 
karş1 onunla eşit mücadele yapacağı bir ortam sunulmuştur. Buna karşın, yatırıma ev sahipliği yapacak ülke de, bir yandan yabancı sermayeyi çekmek isterken, diğer yandan kendi menfaatlerinden taviz vermeyeceği bir sisteme kavuşmuş bulunmaktadır. Bununla birlikte, tarafların menfaat eşitliği tahkime başvurudan başlayarak, hakem heyetinin oluşumu, kararın sonuçları ve kararın icra aşaması da dâhil olmak üzere, her aşamada gözetilmiştir ${ }^{180}$.

Ayrıca, ICSID tahkiminden çıkan kararlar, taraflar için bağlayıcı olacak ve üst makama götürülemeyecektir. Yorumu, düzeltmeyi ve hükümsüz k1lmay1 gerektiren bir durum söz konusu değil ise, taraflar karara uymak ve hükümlerini yerine getirmek zorundadırlar (Söz.m.53/1). Bunun yanı sıra her üye ülke, Sözleşmeye uygun olarak verilmiş her kararı bağlayıcı kabul edecek ve kararın parasal yükümlülüklerini kendi sınırları içerisinde, kendi devlet mahkemesinin nihai bir kararı gibi yerine getirecektir (Söz.m.54/1).

\section{B. Yatırımların Karşıııkıı Korunması ve Teşviki Hakkında İkili Sözleşmeler}

Türkiye ve Kazakistan, çok taraflı sözleşmeler yanı sıra, yatırımların karşılıklı teşviki ve korunmasına ilişkin birçok devlet ile iki taraflı anlaşmalar da imzalamıştır.

Yabancı yatırımların teşviki ve korunmasına ilişkin iki taraflı anlaşmalar, genellikle benzerlik taşır, zira yabancı yatırımlara ilişkin benzer esasları düzenlemektedir.

Örneğin, yabancı yatırımlara ilişkin iki taraflı anlaşmalara bakıldığında, anlaşmanın başında amaca ilişkin hükümler yer almaktadır. Bu amaç genellikle iki devlet arasındaki yatırım akışının karşılıklı olarak korunması ve teşvik edilmesi ile ilgilidir. Daha sonra korunacak yatırımlar ve yatırımcının haklarına ilişkin hükümlere de yer verilmektedir. Bunların yanı sıra, iki taraflı yatırım anlaşmalarında kamulaştırma ve tazminat gibi, yatırım uyuşmazlıklarının çözümüne ilişkin hükümler de yer almaktadır.

sebebi ile sona ermiștir; ya da bir başka olayda "Karatyube International Oil Company LLP” (KIOK) v. Republic of Kazakhstan davasında, Kazakistan'da hidrokarbonların keşfi ve çıkartılması alanında faaliyette bulunan davacı KIOC, ICSID Tahkim Merkezi'ne (Case No. АРБ/08/13) başvurarak, Kazakistan Devleti'nin, mallarına el koyduğunu ve diğer haklarını da sınırlandırdığını ileri sürerek dava açmıştır. Ancak mahkeme, davacının "yatırımcı" sıfatını kanıtlayamadığı gibi, iddialarının da asılsız olduğu gerekçesiyle, davacının taleplerini reddederek, mahkeme masraflarının da davacı tarafından karşılanmasına hükmetmiş̧ir; bu davalar için bkz. Betaneli, https://online.zakon.kz/ Document/?doc_id=35883129\#pos=42;6 Erişim 14.02.2019.

180 Nomer/Ekşi/Öztekin Gelgel, s. 109. 
Özellikle de ev sahibi ülke ile yabancı yatırımcı arasında ortaya çıkan yatırım uyuşmazlıklarının çözümünü düzenleyen hükümler adeta birbirinin tekrar ${ }^{181}$ durumundadır ${ }^{182}$.

Türkiye, bugüne dek yaklaşık 100 ülke ${ }^{183}$ ile yatırımların karşılıklı korunması ve teşvikine yönelik ikili anlaşma akdetmiş iken, Kazakistan ise yaklaşık 50 ülke ${ }^{184}$ ile bu konuda anlaşma imzalamıştır. Ayrıca, Türkiye ile Kazakistan arasındaki yatırımların karşılıklı teşviki ve korunmasına ilişkin ikili anlaşma da 1994 tarihinde imzalanmıştır ${ }^{185}$.

İki taraflı anlaşmalar kapsamında değerlendirilmesi gereken ve yabancı yatırımcıları yakından ilgilendiren bir diğer konu da çifte vergilendirmeyi önleme anlaşmalarıdır. Zira yabancı yatırımcının aynı vergi mevzuu birden fazla vergiye tabi tutuluyorsa, bunun neticesinde yabancı yatırımların büyük ölçüde azalması söz konusu olacaktır. Bu durum da gelişmekte olan ülkeler açısından arzu edilmeyen bir durumdur. Bu sebeptendir ki, ülkeler konu ile ilgili hem iki taraflı hem de çok taraflı anlaşmalar akdetme yoluna gitmektedir $^{186}$.

Türkiye açısından bakıldığında, 2017 yılı itibariyle Türkiye yaklaşık 81 ülke ${ }^{187}$ ile çifte vergilendirmeyi önleme anlaşmaları akdetmiştir. Buna karşın, Kazakistan da yaklaşık 54 ülke ${ }^{188}$ ile aynı konuda ikili anlaşma akdetmiştir. Böylece, Türkiye ve Kazakistan, çifte vergilendirmeyi önleme anlaşmaları ile de yabancı yatırımın ülkelerine gelmesini teşvik etmektedir.

181 Ayrıntılı bilgi için bkz. Nomer/Ekşi/Öztekin Gelgel, s. $122 \mathrm{vd.}$

182 Nomer/Ekşi/Öztekin Gelgel, s. 122.

183 Türkiye'nin yapmış olduğu ikili yatırım anlaşmaları için bkz. https://www.ekonomi. gov.tr/portal/faces/oracle/webcenter/portalapp/pages/navigation-renderer.jspx?_afrLoop $=9730388642525807 \&$ afrWindowMode $=0 \&$ adf.ctrl-state=kp0f997eg_1\&parentPage =yatirim\&\#!\%40\%40\%3F_afrLoop\%3D9730388642525807\%26parentPage\%3Dyatiri m\%26_afrWindowMode\%3D0\%26_adf.ctrl-state\%3Dkp0f997eg_5 Erişim tarihi 05.02.2018.

184 Kazakistan'ın yapmış olduğu ikili yatırım anlaşmaları için bkz.http://invest.mid.gov.kz/ ru/pages/soglasheniya-o-pooshchrenii-i-vzaimnoy-zashchite-investiciy, Erişim tarihi 17.03.2018.

185 RG: 22.09.1994-22059.

186 Gusev, D. V.: “Налоговый Климат Kak Фактор Привлечения Иностранных Инвестиций” (Nalogoviy Klimat Kak Faktor Privlecheniya İnostrannıh İnvestitsiy), Финансы, No: 5, 2000, s. 41.

$187 \mathrm{http}: / /$ www.verginet.net/dtt/1/Ulkeler_4825.aspx Erişim tarihi 14.02.2019.

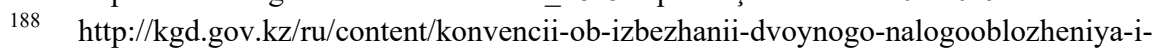
predotvrashchenii-ukloneniya-ot Erişim tarihi 14.02.2019. 
Bu bağlamda belirtmek isteriz ki Türkiye ile Kazakistan arasında çifte vergilendirmenin önlenmesi ile ilgili iki taraflı anlaşma 1996'da imzalanmıştır ${ }^{189}$.

\section{Türkiye ve Kazakistan Cumhuriyetlerinin Akdetmiş Olduğu Diğer Çok Taraflı Sözleşmeler}

Yabancı yatırımları yakından ilgilendiren MIGA ve ICSID Sözleşmeleri dışında, Türkiye ve Kazakistan'ın âkit olduğu veya sadece Türkiye'nin âkit olduğu diğer uluslararası anlaşmalarını da belirtmekte yarar vardır. Her ne kadar yabancı yatırımları bir bütün olarak ele almasalar da, yabanc1 yatırımların bazı yönlerini düzenleyen söz konusu anlaşmaların önemine de dikkat çekmek gerekmektedir. İçeriklerine değinilmeksizin burada bazı uluslararası anlaşmaları yalnızca ismen belirtmeyi uygun görmekteyiz. Bunlara GATT 1947 ve GATT 1994 Dünya Ticaret Örgütü Anlaşması ${ }^{190}$, 1960 tarihli OECD $^{191}$ Anlaşması ve 1994 tarihli Avrupa Enerji Şartı Anlaşması ${ }^{192}$ da örnek olarak gösterilebilir.

Son olarak belirtmek gerekir ki, Türkiye ve Kazakistan, ülkelerine yabancı yatırımların akışını sağlamak amacıyla, gerek çok taraflı ve gerekse de iki taraflı birçok uluslararası anlaşmaları akdetmiş olmakla birlikte, bu yöndeki çalışmalarını halen de sürdürmektedir.

\section{SONUÇ}

Çalışma konumuzu Türk ve Kazak hukukunda yabancı yatırımların teşviki teşkil edip, her iki hukuk açısından konu ile ilgili esasların ortaya konulmasına gayret edilmiştir.

$\mathrm{Bu}$ bağlamda belirtilmeli ki, Türk hukukunda yabancı yatırımlardan bahsedilirken, Kazak hukukunda 2003 yılından beri yalnızca yatırmmlardan söz edilmekte ve buna ilişkin mevzuatın her iki ülkede de birkaç kez değiştiğini görmekteyiz.

Araştırma sonucunda Türkiye ve Kazakistan Cumhuriyetlerinin, yabancı yatırımlara ihtiyaç duyan ülkeler olarak, yabancı yatırımların teşvikine ulusal mevzuatlarında yer verdiği gibi, milletlerarası sözleşmelere de taraf

\footnotetext{
189 RG: $08.11 .1996-22811$.

190 RG: 29.01.1995-22186.

191 Türkiye, OECD'nin kurucu üyesidir.

192 RG: 06.02.2000-23956; Указ Президента Республики Казахстан от 18 октября 1995 г. No: 2537.
} 
olup, yatırımların teşvikini uluslararası düzeyde de sağladığını söylemek mümkündür.

Konuyu ulusal boyutuyla ele aldığımızda görünen o ki, her iki ülkenin yatırım mevzuatlarında yer alan esasların yabancı yatırımların teşvik edilmesi bakımından önemli olduğu, fakat bunların ileride daha da iyileştirilmesi ve dolayısıyla, her iki ülkenin yatırım ikliminin daha da çekici hale getirilmesi söz konusu olabilir. Örneğin Türk hukukunda yabancı yatırımlarda istihdam edilecek personel ile ilgili kolaylaştırılmış kuralların getirilmesi gibi, Kazak hukukunda da, çalışmamızda da belirtmiş olduğumuz gibi, büyük yatırımcı açısından yatırım miktarının azaltılması ile büyük yatırımcı haklarından daha çok yatırımcının istifade edilmesi sağlanabilir. İlaveten, Kazakistan Cumhuriyeti'nde yatırımların kapsamına fikrî ve sınaî haklarının alınmasının da isabetli olacağı görüşündeyiz.

Yabancı yatırımların uluslararası düzeyde teşvik edilmesine gelince, her iki ülkenin de yatırımlarla ilgili iki ve çok taraflı sözleşmelere taraf olduğunu görmekteyiz. Bu durum, yabancı yatırımların Türkiye ve Kazakistan'a akışı bakımından olumlu bir gelişmedir, zira yabancı yatırımcıların aradığ güven unsurunun milletlerarası sözleşmelerle sağlandığ 1 şüphesizdir. Yatırımlarla ilgili iki ülkenin de taraf olduğu çok taraflı sözleşmelerden en önemlileri ise $M I G A$ ve ICSID Sözleşmeleridir.

İki taraflı sözleşmeler kapsamında ise iki ülke tarafından da yabancı yatırımların karşı1ıklı teşviki ve korunmasına ilişkin çok sayıda ikili sözleşmeler imzalanmıştır. Buna ilaveten hem Türkiye hem Kazakistan, ev sahibi ülke sıfatıyla, ülkelerini yabancı yatırımcılar için cazip kılmak amacıyla, birçok ülke ile çifte vergilendirmenin önlenmesine yönelik de ikili sözleşmeler imzalamıştır.

Son olarak belirtilmeli ki, iki taraflı sözleşmeler kapsamında Türkiye ve Kazakistan, kendi aralarında yatırımların karşılıklı teşviki ve korunması gibi, çifte vergilendirmenin önlenmesine ilişkin Sözleşmeler de imzalamıştır. 


\section{KAYNAKÇA}

Açıkalın, Sezgin/Ünal, Seyfettin: Doğrudan Yatırımlar ve Portföy yatırımları, Global ve Yerel Faktörlerin Türkiye Üzerindeki Göreceli Etkisi, Ekin Yayınevi, Bursa, 2008.

Akıncı, Ziya: Milletlerarası Ticari Hakem Kararları ve Tenfizi, DEÜ Hukuk Fakültesi Yayınları, Ankara,1994 (Hakem Kararları).

Akıncı, Ziya: Milletlerarası Özel Hukukta İnşaat Sözleşmeleri, DEÜ Döner Sermaye İşletmesi Yayınları, No: 73, İzmir, 1996 (İnşaat Sözleşmeleri).

Akıncı, Ziya: Milletlerarası Tahkim, 3. Bası, Vedat Kitapçılık, İstanbul, 2013 (Tahkim).

Alpar, Cem: Çok Uluslu Şirketler ve Ekonomik Kalkınma, Turhan Kitabevi, Ankara, 1980.

Arkan Akbıyık, Azra: "Çok Taraflı Yatırım Garanti Kuruluşu”, Ünal Tekinalp'e Armağan, İstanbul, 2003, s. 157-172.

Atabek, Reşat: "Sigorta Akdinin Yorumu", Sigorta Hukuku Dergisi, C. I, S. 2, Ankara, Ağustos 1982, s.125-140.

Ataman Figanmeşe, İnci: "Milletlerarası Ticari Tahkim ve Yatırım Tahkimi Arasındaki Farklar", Public and Private International Law Bulletin, Volume: 31, Issue: 1, s. 91-152.

Ayhan İzmirli, Lale: "Uluslararas1 Yatırım Hukukunda "Yatırım" Kavramı”, SDÜHFD, Vol:8, No:2, Year 2018, s.89-132.

Богатырев, А. Г.: Инвестиционное Право (İnvestitsionnoe Pravo), Rossiyskoe Pravo Yayınevi, Moskova, 1992.

Bozdağlığlu, Yasemin/Evimoğlu, Umut: “Türkiye'de Doğrudan Yabanc1 Sermaye Yatırımlarının Tarihsel Süreçte Gösterdiği Gelişim: Hukuksal ve Ekonomik Yansımaları", Dicle Üniversitesi Sosyal Bilimler Enstitüsü Dergisi, Nisan, 2014, Y11-6, S: 11, s. 32-52.

Bulutoğlu, Kenan: 100 Soruda Türkiye'de Yabancı Sermaye, Gerçek Yayınevi, İstanbul, 1970.

Çelikel, Aysel: "Yabancı Yatırımların Teşviki Amacıyla Yapılan Yeni Yasal Düzenlemeler", Prof. Dr. Gülören Tekinalp'e Armağan, MHB, 423, S. 1-2, 2003, s. 161-177.

Çelikel, Aysel/Öztekin Gelgel, Günseli: Yabancılar Hukuku, 20. Bas1, BETA, İstanbul, 2014. 
Doronina, N. G./Semilyutina, N. G.: “Защиты Иностранных Инвестиций и Российское Законодательство" (Mnogostoronniye Mejdunarodnıye Konventsii v Oblasti Zaşitı İnostrannıh İnvestitsiy i Rossiyskoye Zakonodatelstvo), Gosudarstvo i Pravo, 1992.

Ekşi, Nuray: Yabancıların Türkiye'de Taşınmaz İktisabı, 2. Bası, Beta, İstanbul, 2012.

Erten, Rifat:"ICSID Tahkimi”, BATIDER, C. XIX, S. 4, 1998, s. 205-228.

Farhutdinov, İ. Z.: “Действие международных Договоров в Сфере Иностранных Инвестиций” (Deystviye Mejdunarodnıh Dogovorov v Sfere İnostrannıh İnvestitsiy), Trud1 Moskovskoy Gosudarstvennoy Yuridiçeskoy Akademii, Moskva, 1999, s. 135-140.

Frolkina, E. N.: "Правовое Регулирование Страхования Иностранных Инвестиций в Международном Частном Праве" (Pravovoe Regulirovanie Strahovaniya İnostrannıh İnvestitsiy v Mejdunarodnom Chastnom Prave), Законы России, No:6, Haziran, 2012, s. 90, s. 89-94.

Göğer, Erdoğan: Yabancılar Hukuku, Sevinç Matbaası, 3. Bası, Ankara, 1979.

Demir Gökyayla, Cemile/Süral, Ceyda: "4875 Sayılı Doğrudan Yabancı Yatırımlar Kanunu ve Getirdiği Yenilikler”, Dokuz Eylül Üniversitesi Hukuk Fakültesi Dergisi, Cilt: 6, Say1: 2, 2004, s. 131-167.

Doğan, Vahit: Türk Yabancılar Hukuku, Güncellenmiş 3. Baskı, Savaş Yayınevi, Ankara, 2018.

Gusev, D. V.: "Налоговый Климат Kak Фактор Привлечения Иностранных Инвестиций”, (Nalogoviy Klimat Kak Faktor Privlecheniya İnostrannıh İnvestitsiy), Финансы, No:5, 2000, s. 41-43.

Gürtan, Kenan: Türkiye'de Yatırımlar, İstanbul Üniversitesi Yayınları, İstanbul, 1959.

Hacaloğlu, Tuncay: Yabancı Sermaye ve Türkiye'de Yabancı Sermaye Uygulaması, Uzmanlık Tezi, Başbakanlık DPT Müsteşarlığı, Ankara, 1983.

Işık, Olcay: "Uluslararası Hukukta Yatırım Kavramı. Antlaşmalar Temelinde Bir Değerlendirme", Uluslararası Hukuk ve Politika, Cilt: 7, Say1: 28, 2011, s. 125-145.

Karakoyunlu, Erdoğan: Türkiye'de Yabancı Sermaye Yatırımları ve Yabancı Sermaye Dairesinin 1980 Faaliyetleri Sonuçları, İstanbul, 1981. 
Karluk, S. Rıdvan: Türkiye'de Yabancı Sermaye Yatırımları, Taştan Matbaas1, İstanbul, 1983 (Yabanc1 Sermaye Yatırımları).

Karluk, S. Rıdvan: Uluslararası Ekonomi, Beta, 5.Bas1, İstanbul, 1998 (Ekonomi).

Kayıhan, Şaban/Eski, Mehmet: Uluslararası Ekonomi Hukuku, Seçkin Yayıncılık, Ankara, 2010.

Kılıçkaya, A. Hayati: "Yabancı Sermaye Yatırımı ile Yabancıların Türkiye'de Taşınmaz Edinimlerindeki Mevzuat Değişiklikleri”, Türk Hukuk Enstitüsü Dergisi, Eylül, 2003, s. 10-13.

Kırlı Aydemir, Deniz: Çok Taraflı Yatırım Garanti Kuruluşu (MIGA) ve Yabancı Yatırımların Politik Risklere Karşı Korunması, Legal, İstanbul, 2005.

Krupko, S.: "Международный Центр по Урегулированию Инвестиционных Споров" (Mejdunarodniy Tsentr po Uregulirovaniyu İnvestitsionnı Sporov), Hozyaystvo i Pravo, No: 6, 2002, s. 106-118.

Kubilay, Huriye: Uygulamalı Özel Sigorta Hukuku, Barış Yayınları, 2. Bask1, İzmir, 2003.

Kumkale, Rüknettin: Yabancı Sermayeli Şirketler, Seçkin Yayınevi, 2. Bask1, Ankara, 2003.

Labin, D. K.: Международное Право по Защите и Поощрению Иностранных Инвестиций (Mejdunarodnoe Pravo po Zashite i Pooshreniyu İnostrannıh İnvestitsiy), Wolters Kluwer, Moskova, 2008.

Maulenov, K. S.: Правовое Регулирование Иностранных Инвестиций в Республике Казахстан (Pravovoye Regulirovaniye İnostrannih İnvestitsiy v Respublike Kazakhstan), Almatı, 1998.

Maulenov, K. S.: Государственное Управление и Правовое Регулирование в Сфере Иностранных Инвестиций в Республике Казахстан (Gosudarstvennoye Upravleniye i Pravovoye Regulirovaniye $\mathrm{v}$ Sfere İnostrannıh İnvestitsiy $\mathrm{v}$ Respublike Kazakhstan), Almat1, 2000.

Moroz, S. Р.: Инвестиционное Право (İnvestitsionnoe Pravo), Almat1, 2003.

Nomer, Ergin/Ekşi, Nuray/Öztekin, Günseli: Milletlerarası Tahkim Hukuku, Beta, 4. Bası, İstanbul, 2013. 
Ovchinnikov, A. A/Gushin, V. V.: Инвестиционное Право. Учебник (İnvestitsionnoe Pravo. Uchebnik), Эксмо Yayınevi, Moskova, 2009.

Ökçün, A. Gündüz: Yabancıların Türkiye'de Çalışma Hürriyetleri, Doğuş Matbaacılık ve Ticaret Limited Şirketi Matbaası, Ankara, 1962.

Özel, Sibel: "Doğrudan Yabancı Yatırımlar Kanunu Üzerine Bir Değerlendirme", Prof. Dr. Gülören Tekinalp'e Armağan, MHB, Y1l: 23, 2003, s. 599-617.

Öztekin, Basri: "Yabancı Sermaye Hakkında Görüşler", İstanbul, YASED Yayınları No. 3, 1982.

Paramonov, V. V.: Экономика Казахстана;Экономика, Рынок, Финансы (Ekonomika Kazakhstana; Ekonomika, Rınok, Finansı) (1990-1998), Almat1, G1lım, 2000.

Pekcanıtez, Hakan/Atalay, Oğuz/Özekes, Muhammet: Medeni Usul Hukuku, Ders Kitabı, 5. Bası, Vedat Kitapçılık, İstanbul, 2017.

Perova, М.: "Международная Форма Регуирования Иностранных Инвестиций" (Mejdunarodnaya Forma Regulirovaniya İnostrannı İnvestitsiy), Hozyaystvo i Pravo, No:2, 1999, s. 98-104.

Polat, Malike/Al Kılıç, Şengül: "ICSID Yatırım Tahkimine Konu Olan Cementownia "Nowa Huta" S.A.-Türkiye Uyuşmazlığında "İyi Niyet" ve "Manevi Tazminat" İddialarının Değerlendirilmesi", Public and Private International Law Bulletin, Volume: 34, Issue: 2, s. 59-87.

Sattarova, G.: Право и Иностранные Инвестиции в Республике Казахстан (Pravo i İnostrannıye İnvestitsii v Respublike Kazakhstan), Almaty, 1997.

Seyidoğlu, Halil: Uluslararası İktisat, Güzem Yayınevi, İstanbul 1994.

Suleymenov, M. К.: “Законодательство об инвестициях Республики Казахстан: 25 лет развития", (Kazakistan Cumhuriyeti Yatırımlar Mevzuat1 25.y1lında, "Yer altı kaynakları-Kazakistan Cumhuriyeti Ekonomisinin Temeli" başlıklı 28.04.2017 tarihli konferansında tebliğii.

Şanlı, Cemal: Uluslararası Ticari Akitlerin Hazırlanması ve Uyuşmazlıkların Çözüm Yolları, 2 Bası, İstanbul, 2002.

Şanlı, Cemal/Esen, Emre/Ataman Figanmeşe, İnci: Milletlerarası Özel Hukuk, Vedat Kitapçı1ık, İstanbul, 2016.

Tekinalp, Gülören: Türk Yabancılar Hukuku, Beta, 8. Bası, İstanbul, 2003.

Tiryakioğlu, Bilgin: Doğrudan Yatırımların Uluslararası Hukukta Korunmas1, Dayınlarlı Hukuk Yayınları, Ankara, 2003. 
Turanlı, Hüsnü: Doğrudan Yabancı Yatırımların Hukuki Çerçevesi, Gazi Üniversitesi Sosyal Bilimler enstitüsü Özel Hukuk Anabilim Dalı, yayınlanmamış doktora tezi, 2008.

Uludăg, Ramazan: Türkiye'de Yabancı Sermaye Uygulaması, Atıf Matbaacılık, Ankara 1991.

Uras, Güngör: Türkiye'de Yabancı Sermaye Yatırımları, Formül Matbaas1, İstanbul, 1979.

Veselkova, Е. Е.: “Некоторые Правовые Аспекты Соглашений по Защите Инвестиций” (Nekotoriye Pravoviye Aspektı Soglaşeniy po Zaşite İnvestitsiy), Zakon i Pravo, no:10, 2002, s. 51-54.

Yılmaz, Cengiz: "Türkiye'de Yabancı Sermaye ve Kârlılık", Prof. Dr. Muammer Aksoy'a Armağan, Ankara, 1991, s. 475-485.

Yılmaz, İlhan: Uluslararası Yatırım Uyuşmazlıklarının Tahkim Yoluyla Çözümü ve ICSID, Beta, İstanbul, 2004.

\section{İnternet Adresleri :}

Dikmen, Ahmet Alpay/Karahanoğulları, Onur: "Doğrudan Yabancı Yatırımlar Kanunu Tasarısı Hakkında Değerlendirme", http://www.bilkent.edu.tr / yeldanbs/Yazilar_Uye/DikmenKara.html

Betaneli, Ketevan: “Арбитражные Дела в Нефтегазовой Отрасли с Үчастием Казахстана" (Arbitrajnıe Dela s Uchastiem Kazahstana), https://online.zakon.kz/Document/?doc_id=35883129\#pos=6;-155

http://www.ekodialog.com/osmanli_ekonomisi/osmanli-devletinde-yabancisermaye.html

http://herdem.av.tr/tr/dorudan-yabanc-yatrmlar-ve-trkiye/

www.tbmm.gov.tr/sirasayi/dönem22/yil01/ss142m.html

http://www.katiad.kz

http://kidi.gov.kz/public/publications/483

http://e-law.kz/sovety/13-blog/72-zashchita-investorov.html

http://www.memleket.com.tr/kazakistanda-dogrudan-yatirim-yuzde-40-artti$1094424 \mathrm{~h}$

https://www.miga.org/who-we-are/member-countries/

https://icsid.worldbank.org/en/Pages/about/Database-of-Member-States.aspx http://invest.mid.gov.kz/ru/pages/soglasheniya-o-pooshchrenii-i-vzaimnoyzashchite-investiciy 
http://www.verginet.net/dtt/1/Ulkeler_4825.aspx

http://kgd.gov.kz/ru/content/konvencii-ob-izbezhanii-dvoynogo-

nalogooblozheniya-i-predotvrashchenii-ukloneniya-ot

http://rfcaratings.kz/6579

https://www.italaw.com/sites/default/files/case-documents/ita0289_1.pdf

https://www.italaw.com/sites/default/files/case-documents/italaw3126.pdf 
